\title{
Molecular Dissection of the Mechanism by Which Potexvirus Triple Gene Block Proteins Mediate Cell-to-Cell Transport of Infectious RNA
}

\author{
Tony J. Lough, ${ }^{1,2}$ Khalid Shash, ${ }^{1}$ Beatriz Xoconostle-Cázares, ${ }^{1}$ Katrina R. Hofstra, ${ }^{2}$ David L. Beck, ${ }^{2}$ \\ Ezequiel Balmori, ${ }^{2}$ Richard L. S. Forster, ${ }^{2}$ and William J. Lucas ${ }^{1}$ \\ ${ }^{1}$ Section of Plant Biology, Division of Biological Sciences, University of California, Davis 95616, U.S.A.; \\ ${ }^{2}$ Horticulture and Food Research Institute of New Zealand, Molecular Genetics Group, Private Bag 92 \\ 169, Auckland, New Zealand \\ Accepted 6 May 1998.
}

The triple gene block (TGB; consisting of proteins TGB1$3)$ and coat protein $(\mathrm{CP})$ of white clover mosaic potexvirus (WCIMV) are required for cell-to-cell movement of viral RNA. Cell-to-cell spread of WCIMV mutants in which the TGB open reading frames had been mutated was rescued in transgenic plants expressing specific TGB proteins (TGBPs). This indicated that there are no requirements for the synthesis in cis of viral TGBPs. These transgenic plants provided an experimental framework to explore the roles performed by the TGBPs and $C P$ in cell-to-cell movement of WCIMV RNA. Microinjection experiments established that TGB1 functions as the WCIMV cell-to-cell movement protein (MP). Furthermore, combined microinjection and dual-channel confocal laser scanning microscopy provided direct evidence that infectious transcripts of WCIMV move cell to cell as a ribonucleoprotein complex, consisting of single-stranded RNA, TGB1, and CP. Movement of this ribonucleoprotein complex displayed an absolute requirement for the presence of both TGB2 and TGB3. A model consistent with these findings is presented.

Additional keywords: macromolecular trafficking, plasmodesmata.

The movement of plant viruses from cell to cell is an essential component of the viral life cycle. It is well accepted that during the infection process most plant viruses move via plasmodesmata (PD) (Hull 1989; Maule 1991; Deom et al. 1992). In higher plants, PD are plasma membrane-lined, intercellular connections, consisting of a cytoplasmic annulus and a central appressed form of the endoplasmic reticulum (ER) that establishes an endomembrane continuum between neighboring cells (Lucas et al. 1993). Proteins embedded in the plasma membrane and appressed ER divide the PD annulus into microchannels (Ding et al. 1992b), and it is via this pathway that intercellular transport is considered to take place (see Lucas et al. 1993; Lucas and Gilbertson 1994).

The functions performed by PD are only now beginning to be elucidated. This elucidation includes the observation that

Corresponding author: William J. Lucas; Telephone: +1 (530) 752 1093; Fax: +1 (530)752 5410; E-mail: wjlucas@ucdavis.edu the homeobox protein, KNOTTED-1, potentiates its own movement and that of its mRNA, through PD, demonstrating a role in cell-to-cell communication (Lucas et al. 1995). In addition, Kühn et al. (1997) have recently provided indirect evidence that, in a number of plant species, mRNA for the integral membrane protein, sucrose transporter 1 , can be transported via PD into functional sieve elements. It has also been suggested that plant viruses evolved the capacity to exploit this endogenous PD macromolecular trafficking capacity (Lucas and Wolf 1993; Gilbertson and Lucas 1996); however, the nature of the virus/ PD interaction involved in cellto-cell movement and long-distance transport remains largely unresolved.

Most viruses encode one or more movement proteins (MPs) (Deom et al. 1992) that are required for infection. The MPs of tobacco mosaic tobamovirus (TMV), red clover necrotic mosaic dianthovirus (RCNMV), bean dwarf mosaic geminivirus (BDMV), cucumber mosaic cucumovirus (CMV), and two potyviruses, bean common mosaic necrosis virus (BCMNV) and lettuce mosaic virus (LMV), have been expressed in Escherichia coli, fluorescently labeled, and shown by microinjection of plant cells to traffick extensively from cell to cell (Fujiwara et al. 1993; Noueiry et al. 1994; Ding et al. 1995; Nguyen et al. 1996; Rojas et al. 1997). Additionally, these proteins have the capacity to induce an increase in PD size exclusion limit (SEL) from its basal value of $1 \mathrm{kDa}$ to 10 to 20 kDa (see Lucas and Gilbertson 1994; Ghoshroy et al. 1997). Viral MPs from infected and transgenic plants have been localized to PD (Tomenius et al. 1987; Linstead et al. 1988; Atkins et al. 1991; Ding et al. 1992a; Epel et al. 1996). Furthermore, TMV MP-green fluorescent protein (GFP; from Aequorea victoria) fusions have been used to show that this viral MP co-localizes with the cytoskeleton (Heinlein et al. 1995; McLean et al. 1995, 1997; Padgett et al. 1996). These data suggest that plant viruses may use the cytoskeleton as a means of intracellular movement and delivery to PD.

Plant viral MPs also have the capacity to bind nucleic acids in a non-sequence-specific manner (see Ghoshroy et al. 1997). Microinjection of BDMV, RCNMV, CMV, BCNMV, and LMV MPs, with fluorescently labeled nucleic acid, resulted in cell-to-cell transport of these nucleic acid molecules (Fujiwara et al. 1993; Noueiry et al. 1994; Ding et al. 1995; Nguyen et 
al. 1996; Rojas et al. 1997). These results demonstrated that MPs have the capacity to move from cell to cell, dilate PD, and potentiate the trafficking of viral nucleic acids. The form in which infectious viral material moves between cells (whether as virions, viral nucleic acids, and/or nucleoprotein complexes) may vary for different viruses. A number of viruses require their coat protein $(\mathrm{CP})$ for cell-to-cell movement, while others do not (see Lucas and Gilbertson 1994; Gilbertson and Lucas 1996). In the latter instance, the virus is likely to move between cells as a ribonucleoprotein complex rather than as a virion.

Several groups of plant RNA viruses appear to employ a more complex cell-to-cell movement strategy involving not one but three proteins translated from overlapping open reading frames (ORFs), termed the triple gene block (TGB). These proteins are henceforth referred to as TGB1, TGB2, and TGB3. These viruses include the potex-, carla-, benya- (furo-), and hordeiviruses, as well as several unclassified plant viruses of the Sindbis virus-like superfamily (Beck et al. 1994). Among the potexviruses, TGB1, the $5^{\prime}$-most gene of the TGB ( 24 to $28 \mathrm{kDa}$ protein) has been shown to encode domains present in RNA helicases (Habili and Symons 1989), and the encoded protein displays ATPase and RNA binding properties (Rouleau et al. 1994). The subcellular localization of these proteins is variable in that they have been detected in cytoplasmic inclusions as well as in the soluble cytoplasmic fraction (Davies et al. 1993; Rouleau et al. 1994; Chang et al. 1997). Although localization studies have not detected these proteins within the PD, the potato virus X (PVX) TGB1 has been shown to be associated with an increase in the SEL of PD (Angell et al. 1996). A fourth protein, the CP, is also required for potexvirus cell-to-cell movement (Chapman et al. 1992; Forster et al. 1992; Baulcombe et al. 1995). Interest- ingly, electron microscopic studies conducted on plants infected with foxtail mosaic potexvirus and cactus virus $\mathrm{X}$ (Rouleau et al. 1995) and PVX (Oparka et al. 1996) revealed that the $\mathrm{CP}$ accumulated in PD. Collectively, these studies suggest a role for the potexvirus $\mathrm{CP}$, exclusive of encapsidation, possibly as part of a ribonucleoprotein complex involved in mediating cell-to-cell transport of viral RNA through PD.

In this study we establish the roles performed by the TGB proteins (TGBPs) and CP in cell-to-cell transport of white clover mosaic potexvirus (WCIMV) RNA. Based on the functional properties associated with viral MPs (i.e., the ability to increase PD SEL, bind nucleic acids, and mediate the trafficking of nucleic acids between cells), TGB1 was identified as the WCIMV MP. Furthermore, we present direct evidence consistent with the hypothesis that infectious transcripts of WCIMV move cell to cell as a ribonucleoprotein complex consisting of single-stranded (ss) RNA, TGB1, and the CP. Movement of this ribonucleoprotein complex displayed an absolute requirement for the presence of both TGB2 and TGB3. A model consistent with these findings is presented.

\section{RESULTS}

To elucidate the role of the TGBPs in the cell-to-cell spread of the potexvirus infectious agent, we carried out parallel viral complementation and TGBP microinjection studies. For this purpose, a range of WCIMV mutants was required, each expressing a modified TGBP. A wild-type clone, pWCIMV-4 (Beck et al. 1990), was used to construct the appropriate TGB mutants; specific details of the WCIMV mutants employed in the present study are presented in Figure 1A. Infectious transcripts of p7c, p13a, p13b, p26a, and p26c were able to repli-
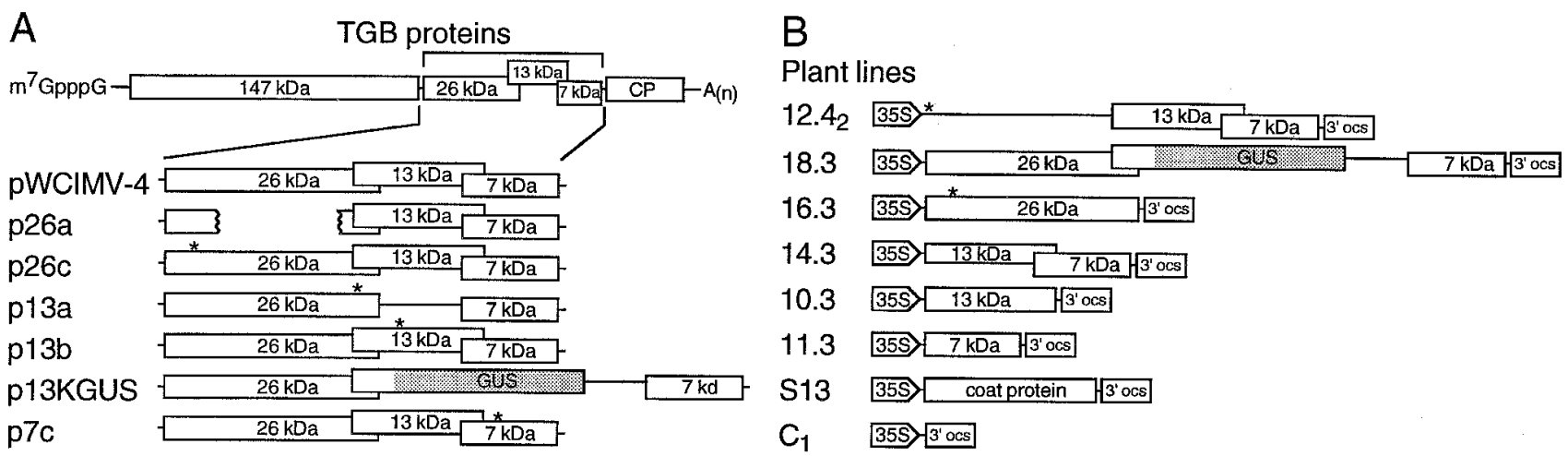

Fig. 1. White clover mosaic potexvirus (WCIMV) triple gene block (TGB) mutants and TGB proteins (TGBPs) expressed in transgenic Nicotiana benthamiana for use in viral complementation and microinjection studies. A, WCIMV genome is composed of four nonstructural open reading frames (ORFs) (designated by the size of the encoded protein) plus the coat protein (CP). The 147-kDa ORF is the putative replicase gene followed by the TGB. An infectious clone, designated pWCIMV-4 (Beck et al., 1990), was used to generate WClMV TGB mutants p26a, p26c, p13a, and p13b. For a description of these mutants, see Beck et al. (1991). WCIMV mutant p13KGUS expressed the Escherichia coli UidA gene product, $\beta$-glucuronidase (GUS), as an inframe translational fusion inserted following $\mathrm{G}_{49}$ (numbering relative to the $\mathrm{N}$ terminus) of TGB2. The GUS coding sequence had an $\mathrm{N}$-terminal extension derived from the TGB2 ORF and was designed to retain its own termination codon. WCIMV mutant p7c expressed a modified TGB3 with a $\mathrm{G}_{34}$ to $\mathrm{E}_{34}$ mutation. Residue $\mathrm{G}_{34}$ is located within a conserved motif (Foster et al. 1990). Mutations have been designated as follows: large deletion by a break in the ORF; sites of base substitutions by asterisks; straight lines indicate mutations that give rise to untranslated regions. B, Transgenic Nicotiana benthamiana plant lines expressing various ORFs of the WCIMV TGB and CP under transcriptional control of the cauliflower mosaic virus (CaMV) $35 \mathrm{~S}$ promoter and octopine synthase (OCS) termination sequences. Nomenclature and ORF designations as in (A). Plant line $12.4_{2}$ expressed only TGB2+3 and not TGB1 as its initiation codon was modified from AUG to TCC. Line 18.3 expressed TGB1 ORF, the GUS coding sequence as an inframe translational fusion from $\mathrm{G}_{49}$ of TGB2 ORF and TGB3 ORF. Line 16.3 expressed the modified TGB1 (residues $\mathrm{G}_{33}-\mathrm{K}_{-} \mathrm{S}_{35}$ changed to $\mathrm{A}_{33}-\mathrm{A}-\mathrm{A}_{35}$ ). Plant lines $14.3,10.3,11.3$, and $\mathrm{S} 13$ expressed TGB2+3, TGB2, TGB3, and the CP, respectively. Plant line $\mathrm{C}_{1}$, expressing the empty cassette, was employed as the vector control. Subscripts following each plant line serve to designate progeny derived from a specific transformant. 
cate in protoplasts, suggesting that the apparent lack of accumulation of each of these TGB mutants, within inoculated plants, was due to an inability to spread, rather than to a block in replication (Beck et al. 1991). Histochemical staining for $\beta$ glucuronidase (GUS) activity, following inoculation of Nicotiana benthamiana, confirmed that p13KGUS was unable to move from cell to cell (data not shown). Additionally, immunoblot analysis with a CP-specific antiserum confirmed that mutant $\mathrm{p} 7 \mathrm{c}$ did not accumulate to detectable levels in inoculated leaves of $N$. benthamiana (see Figure 2B).

\section{TGBPs expressed in transgenic plants complement WCIMV TGB mutants.}

A description of the TGB ORFs expressed in transgenic $N$. benthamiana plants is presented in Figure 1B. These plant lines were subjected to Northern (RNA) blot analysis to establish that the respective transgene was being transcribed. As shown in Figure 2A, transcripts of the expected size were identified with a random-primed WCIMV TGB+CP polymerase chain reaction (PCR) product hybridized to poly(A)+ RNA that was extracted from leaf tissue of each line. (Plant lines $18.3_{2}, 12.4_{2}, 11.3_{1}, 10.3_{3}$, and $14.3_{1}$ should express transcripts that were $3.1,1.4,0.55,0.4$, and $0.7 \mathrm{~kb}$, respectively, in size.) The capacity of these transgenically expressed TGBPs to rescue the WCIMV TGB mutants was tested by mechanically inoculating WCIMV TGB mutant transcripts onto transgenic plants expressing the appropriate combination of WCIMV TGBPs.

Representative immunoblot analyses (with a WCIMV CPspecific antiserum) presented in Figure 2B show that WCIMV
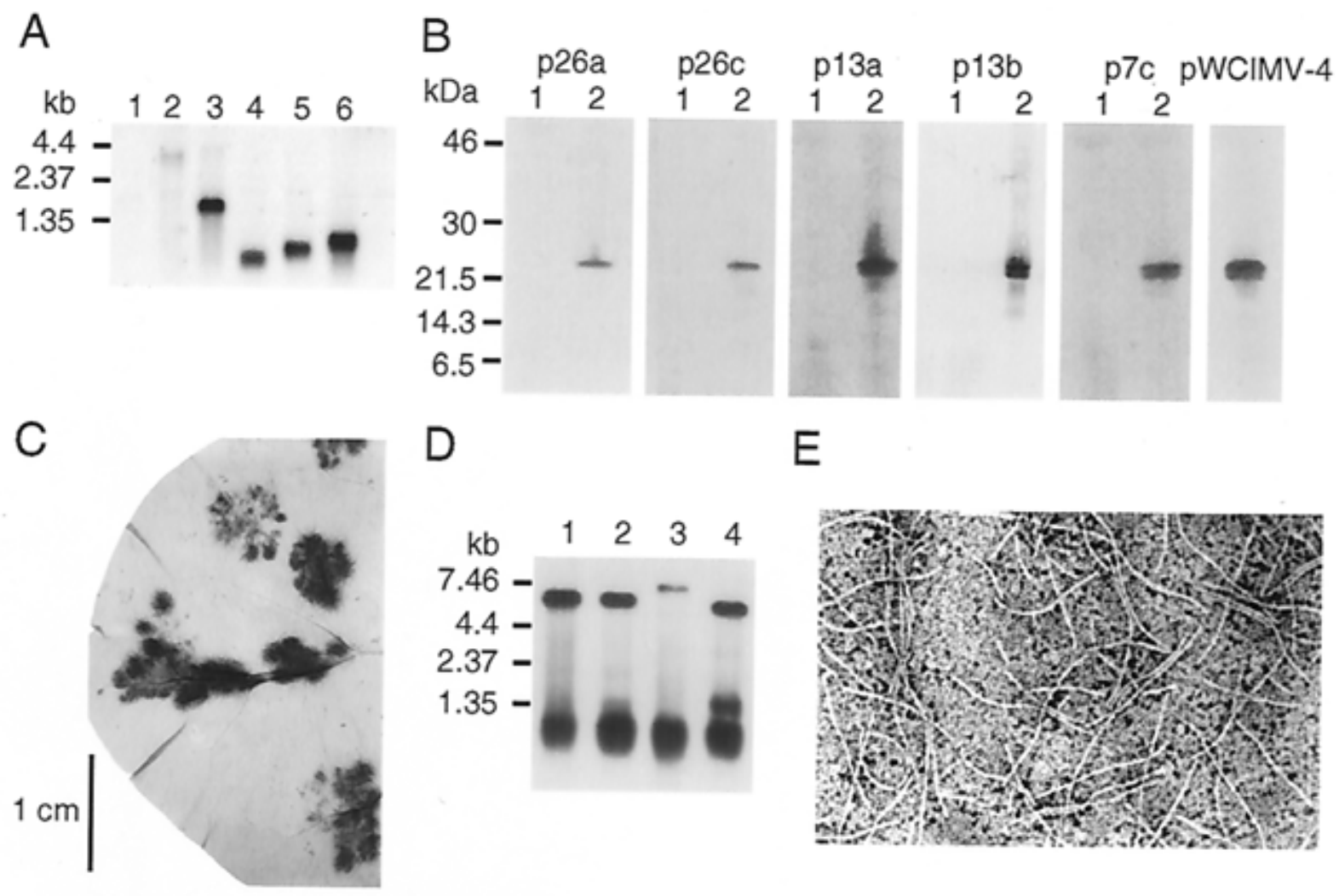

Fig. 2. Complementation of white clover mosaic potexvirus (WCIMV) triple gene block (TGB) mutants by transgenic Nicotiana benthamiana plants expressing WCIMV TGB proteins (TGBPs). A, Northern (RNA) analysis of transcript levels in transgenic plants expressing WCIMV TGB sequences. Poly(A)+ RNA was extracted from leaves, electrophoresed on agarose formaldehyde gels, and then transferred to nitrocellulose. The membrane was hybridized with a probe specific for the WCIMV TGB and coat protein (CP). Lane 1, plant line $\mathrm{C}_{1}$ (vector control plants); lane 2, plant line 18.3 ${ }_{2}$; lane 3 , plant line $12.4_{2}$; lane 4 , plant line $11.3_{1}$; lane 5, plant line $10.3_{3}$; lane 6 , plant line $14.3_{1} . \mathbf{B}$, Immunoblot analysis of WClMV wild-type (pWCIMV-4) and viral TGB mutant. Presence of virus was determined by CP accumulation within inoculated leaves. Infectious clones of WCIMV TGB mutants (as indicated) were inoculated onto vector control (line $\mathrm{C}_{1}$ ) plants (lane 1) and transgenic plant lines expressing WClMV TGB ORFs (lines $18.3_{2}, 18.3_{3}, 12.4_{2}$, $12.4_{2}$, and $12.4_{2}$, respectively) (lane 2). Wild-type WCIMV (pWCIMV-4) was inoculated onto vector control plants (line $\mathrm{C}_{1}$ ). Crude protein extracts were prepared 5 days post inoculation and fractionated by sodium dodecyl sulfate-polyacrylamide gel electrophoresis (SDS-PAGE) before being transferred to nitrocellulose. Immunoblots were probed with WCIMV CP-specific antisera, followed by alkaline phosphatase-conjugated goat anti-rabbit IgG. Alkaline phosphatase activity was visualized with nitroblue tetrazolium chloride, 5-bromo-4-chloro-3-indolylphosphate p-toluidine salt (NBT/BCIP). (molecular mass standards indicated on the left.). C, Histochemical detection of $\beta$-glucuronidase (GUS) activity, 8 days after inoculating leaves of plant line $10.3_{3}$ (expressing wild-type TGB2) with mutant p13KGUS transcripts. D, Northern analysis demonstrating accumulation of wild-type and WClMV TGB mutant RNA in inoculated leaves. Poly(A)+ RNA was extracted from leaves 8 days post inoculation: lane 1, clone pWCIMV-4 inoculated onto vector control plant line $\mathrm{C}_{1}$; lane 2 , clone p13a inoculated onto plant line $12.4_{2}$; lane 3 , clone p13KGUS inoculated onto plant line $12.4_{2}$; lane 4 , clone p7c inoculated onto plant line $12.4_{2}$. RNA was electrophoresed on agarose formaldehyde gels and then transferred to nitrocellulose. Membrane was hybridized with a probe specific for the WCIMV TGB and CP. E, Electron micrograph of WCIMV TGB mutant particles. Serologically specific electron microscopy, with a WClMV CP-specific antibody, was performed on extracts obtained from plant line $12.4_{2}$ leaves (expressing wild-type TGB2 and TGB3) inoculated with clone p13a transcripts. Virions were negatively stained with $1.5 \%$ phosphotungstate and viewed by transmission electron microscopy. 
TGB mutants were efficiently rescued by complementation when inoculated onto the complementary transgenic plants, whereas complementation was not detected with control plants. The results presented in Table 1 summarize our complementation experiments performed with each TGB mutant on plants from the appropriate lines (Fig. 1B). Viral mutants p26a and p26c were complemented by transgenic plants expressing TGB1 (Fig. 2B; lines 18.32-5,9). However, plants expressing a mutant form of TGB1 (line $16.3_{\mathrm{A}}$ ) were unable to complement WCIMV mutants p26a or p26c (data not presented). In addition, WCIMV TGB mutants p26a and p26c were not complemented by plant lines expressing TGB2 and TGB3 (e.g., line 12.42).

Expression of TGB2, alone, in transgenic plants (lines $10.3_{3,5,7}$ ), was sufficient to complement TGB mutants p13a and p13b (Table 1). Figure $2 \mathrm{C}$ illustrates that mutant p13KGUS was able to spread within leaves that expressed TGB2 (line 10.3 $)$. However, p13KGUS failed to spread when inoculated onto control $N$. benthamiana plants transformed with the binary vector only (line $\mathrm{C}_{1}$; data not shown). In addition, plants expressing both TGB2 and TGB3 (lines 12.4, $14.3_{1,3,5}$ ) were also able to complement TGB2 mutants p13KGUS, p13a, and p13b (Fig. 2B, Table 1). Similar results were obtained with respect to complementation of the WCIMV p7c mutant by plants that expressed TGB3 (Table 1, line 11.31). As anticipated, mutant $\mathrm{p} 7 \mathrm{c}$ was also complemented by plants expressing both TGB2 and TGB3 (lines $12.4_{2}, 14.3_{1,3,5}$ ), whereas plants expressing TGB1 (line $18.3_{2,5,7,9}$ ) failed to complement this mutant. Taken together, these results demonstrated that plants of line $18.3_{2,5,7,9}$ expressed TGB1 but not TGB3, despite the presence of the TGB3 ORF within the transgene transcript.

In all cases, mutant virus infection was similar to that of wild-type WCIMV. Figure 2B and D show, by immunoblot and Northern blot analyses, that the level of TGB mutant accumulation in the inoculated leaf was similar to that observed during wild-type infection. In addition, Figure 2D demonstrates that the ratio of CP subgenomic RNA to genomic RNA was unaltered, relative to wild-type infections. (Note that mutant virus p13KGUS had a larger genomic RNA band due

Table 1. Complementation of white clover mosaic potexvirus (WCIMV) triple gene block (TGB) mutants by transgenic Nicotiana benthamiana plants expressing specific WCIMV TGB proteins (TGBPs) ${ }^{\mathrm{a}}$

\begin{tabular}{|c|c|c|c|c|c|c|c|}
\hline \multirow[b]{2}{*}{$\begin{array}{l}\text { Transgenic } \\
\text { line }\end{array}$} & \multirow[b]{2}{*}{$\begin{array}{l}\text { TGBP } \\
\text { expression }\end{array}$} & \multicolumn{6}{|c|}{ WCIMV TGB mutant } \\
\hline & & p26a & p26c & p13a & p13b & $\begin{array}{l}\text { p13K- } \\
\text { GUS }^{\mathbf{b}}\end{array}$ & p7c \\
\hline $18.3_{2-5,9}{ }^{\mathrm{b}}$ & TGB1 & + & + & & & & - \\
\hline $12.4_{2}$ & TGB2+3 & - & - & + & + & + & + \\
\hline $14.3_{1,3,5}$ & TGB2+3 & - & - & + & + & + & + \\
\hline $10.3_{3,5,7}$ & TGB2 & & & + & + & & \\
\hline $11.3_{1}$ & TGB3 & & & & & & + \\
\hline $16.3_{\mathrm{A}}$ & TGB1-GKS ${ }^{\mathrm{c}}$ & - & - & & & & \\
\hline \multicolumn{8}{|c|}{$\begin{array}{l}\text { a WCIMV TGB mutants and transgenic plants expressing the WCIMV } \\
\text { TGBPs were as described in Figure } 1 \mathrm{~A} \text { and } \mathrm{B} \text {. Virus accumulation was } \\
\text { determined by immunoblot analysis ( } \pm \text { ) with a WCIMV coat protein- } \\
\text { specific antiserum. In each case there was no apparent accumulation of } \\
\text { virus on vector control transgenic plants (line } \mathrm{C}_{1} \text { ), as determined by } \\
\text { immunoblot analysis. } \\
\text { b A translational fusion of the } \beta \text {-glucuronidase (GUS) coding sequence } \\
\text { was engineered from G49 of TGB2. } \\
\text { c TGB1 mutant incorporating } \mathrm{G}_{33}-\mathrm{K}_{-}-\mathrm{S}_{35} \text { to } \mathrm{A}_{35}-\mathrm{A}-\mathrm{A}_{35} \text {. }\end{array}$} \\
\hline
\end{tabular}

to the insertion of the GUS coding sequence within the TGB2 coding sequence [Fig. 2D, lane 3], and the additional bands at $1.35 \mathrm{~kb}$ [Fig. 2D, lanes 2 and 4] likely represent crossreactivity with host transcripts.) Serologically specific electron microscopy was used to investigate the capacity of each WCIMV mutant virus (p26a, p26c, p13a, p13b, p13KGUS, and $\mathrm{p} 7 \mathrm{c}$ ) to form particles. An example of WCIMV mutant p13a particles is presented in Figure 2E; similar results were obtained with all other mutant viruses examined. These studies demonstrated, unambiguously, that encapsidation was not compromised by mutating each of the TGB coding sequences. Finally, all WCIMV TGB mutants were rescued not only in terms of cell-to-cell movement, in the inoculated leaf, but also with respect to long-distance transport, resulting in the systemic accumulation of each mutant virus (T. J. Lough, unpublished results).

\section{Capacity of WCIMV TGB proteins to increase plasmodesmal SEL.}

It is generally accepted that viral cell-to-cell movement is associated with an MP-induced increase in plasmodesmal SEL (Lucas and Gilbertson 1994; Gilbertson and Lucas 1996). Transgenic $N$. benthamiana plants used for complementation of WCIMV TGB mutants provided a direct means for determining which, if any, of the TGBPs was capable of inducing an increase in plasmodesmal SEL. Fluorescein isothiocyanate (FITC)-labeled dextrans (F-dextrans) were microinjected into mesophyll cells within mature leaves of transgenic N. benthamiana plants. For these experiments, the low molecular mass (457 daltons) and membrane-impermeable fluorescent probe, Lucifer yellow $\mathrm{CH}(\mathrm{LYCH})$, was first used as a posi-

Table 2. Influence of transgenically expressed white clover mosaic potexvirus (WCIMV) triple gene block proteins (TGBPs) on Nicotiana benthamiana mesophyll plasmodesmata

\begin{tabular}{|c|c|c|c|c|}
\hline \multirow[b]{2}{*}{$\begin{array}{l}\text { Transgenic } \\
\text { line }\end{array}$} & \multirow[b]{2}{*}{$\begin{array}{c}\text { Protein } \\
\text { expressed }^{\mathrm{a}}\end{array}$} & \multirow[b]{2}{*}{ Injected material } & \multicolumn{2}{|c|}{ Microinjections } \\
\hline & & & $\begin{array}{l}\text { Total } \\
\text { (no.) }\end{array}$ & $\begin{array}{c}\text { Movement } \\
\text { (no. [\%]) }\end{array}$ \\
\hline \multirow[t]{2}{*}{$\mathrm{C}_{1}$} & - & $\mathrm{LYCH}^{\mathrm{c}}$ & 23 & $23(100)$ \\
\hline & - & 10-kDa F-dextran ${ }^{\mathrm{c}}$ & 34 & $3(9)$ \\
\hline \multirow[t]{2}{*}{10.33} & TGB2 & $\mathrm{LYCH}$ & 16 & $15(94)$ \\
\hline & TGB2 & 10-kDa F-dextran & 10 & $1(10)$ \\
\hline \multirow[t]{2}{*}{11.31} & TGB3 & $\mathrm{LYCH}$ & 18 & $17(94)$ \\
\hline & TGB3 & 10-kDa F-dextran & 11 & $1(9)$ \\
\hline \multirow[t]{2}{*}{14.31} & TGB2+3 & $\mathrm{LYCH}$ & 12 & $12(100)$ \\
\hline & TGB $2+3$ & 10-kDa F-dextran & 24 & $3(13)$ \\
\hline \multirow[t]{2}{*}{12.42} & TGB $2+3$ & $\mathrm{LYCH}$ & 78 & $75(96)$ \\
\hline & TGB $2+3$ & 10-kDa F-dextran & 72 & $8(11)$ \\
\hline \multirow[t]{4}{*}{18.39} & TGB1 & $\mathrm{LYCH}$ & 12 & $12(100)$ \\
\hline & TGB1 & 10-kDa F-dextran & 13 & $12(92)$ \\
\hline & TGB1 & $20 \mathrm{kDa}$ F-dextran & 12 & $10(83)$ \\
\hline & TGB1 & $40 \mathrm{kDa}$ F-dextran & 10 & $2(20)$ \\
\hline \multirow[t]{2}{*}{$12.4_{2} \times \mathrm{S} 13$} & $\mathrm{TGB} 2+3+\mathrm{CP}$ & $\mathrm{LYCH}$ & 51 & $47(92)$ \\
\hline & $\mathrm{TGB} 2+3+\mathrm{CP}$ & 10-kDa F-dextran & 33 & $2(6)$ \\
\hline \multirow[t]{3}{*}{$16.3 \mathrm{~A}$} & TGB1-GKS & $\mathrm{LYCH}$ & 17 & $17(100)$ \\
\hline & TGB1-GKS & 10-kDa F-dextran & 22 & $11(50)$ \\
\hline & TGB1-GKS & 20 kDa F-dextran & 10 & $1(10)$ \\
\hline
\end{tabular}

a Details for TGBP expression as in Table 1.

${ }^{b}$ Number of injections and percentage of total injections in which the fluorescently labeled probe moved from the injected cell into surrounding tissue. Data are derived from at least 5 different plants of each line.

${ }^{c}$ Lucifer yellow $\mathrm{CH}(\mathrm{LYCH})$ and fluorescein isothiocyanate (FITC)labeled dextran (F-dextran). 
tive control to ensure that the PD were not closed as a result of tissue preparation.

As illustrated by the microinjection data presented in Table 2 , control $N$. benthamiana plants (line $\mathrm{C}_{1}$ ) did not permit the movement of $10-\mathrm{kDa}$ F-dextran. Similar experiments conducted on plants expressing TGB2 (line 10.3 ), TGB3 (line $11.3_{1}$ ) and both TGB2 and TGB3 (lines $12.4_{2}$ and $14.3_{1}$ ) es- tablished that the $10-\mathrm{kDa}$ F-dextran was retained within the injected mesophyll cell (Table 2). (In addition, these data suggested that a background level of cell-to-cell trafficking of fluorescently labeled molecules was in the range of 9 to $13 \%$. We generally considered a frequency of movement 2 to 3 times this value to constitute evidence of cell-to-cell movement of macromolecular trafficking.) Figure $3 \mathrm{~A}$ presents a
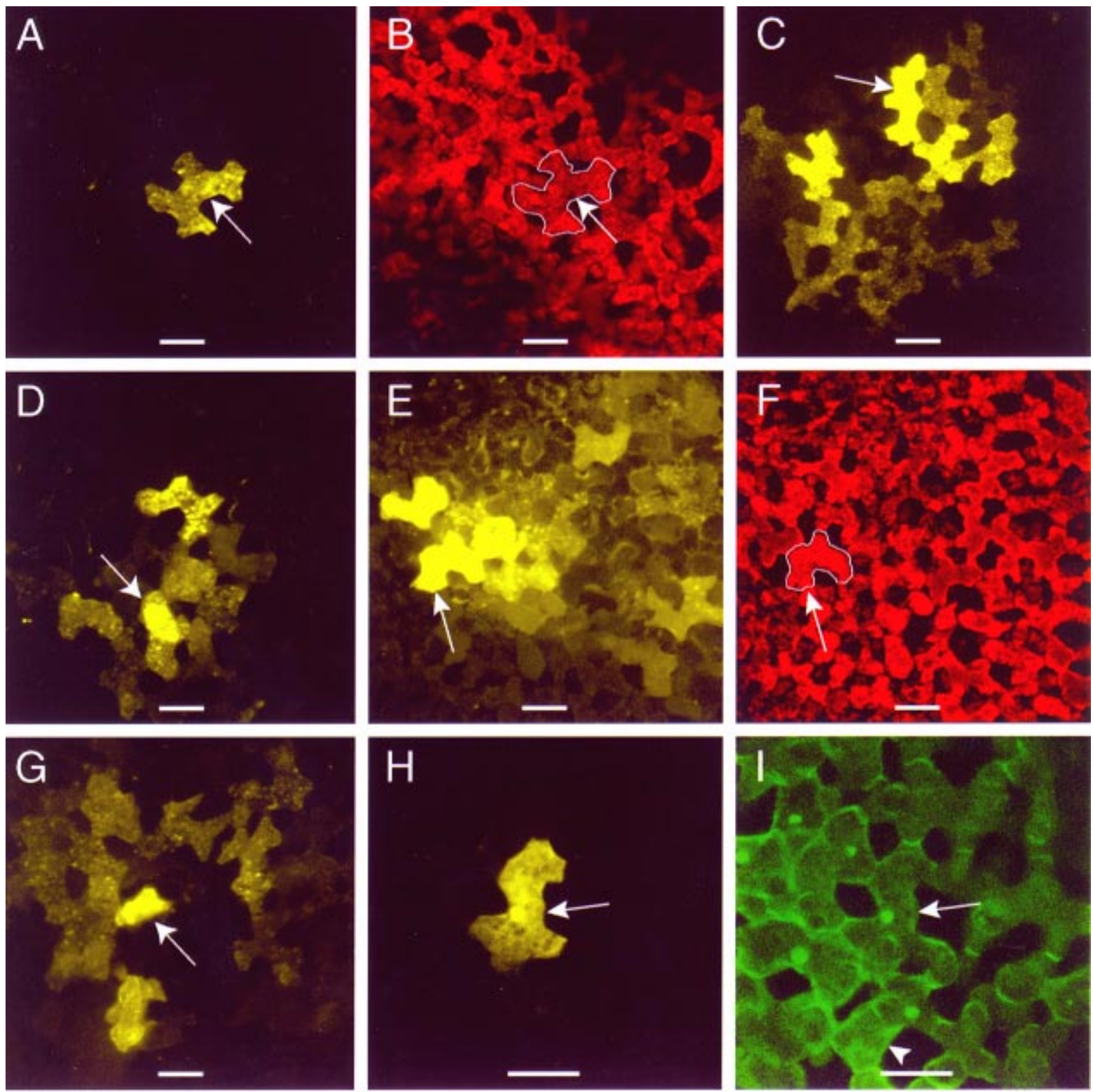

Fig. 3. Cell-to-cell movement of microinjected, fluorescently labeled molecules between mature mesophyll cells of Nicotiana benthamiana. All images for microinjection experiments were collected $5 \mathrm{~min}$ after probe was introduced into the target mesophyll cell (injected cell identified by an arrow). A Leica TCS-4D upright confocal laser scanning microscope was used to image cells. Fluorescence intensities are presented in false color, with images being composed of 8 to 10 optically stacked sections. (Scale bars represent $50 \mu \mathrm{m}$.) A, Fluorescence associated with 10-kDa fluorescein isothiocyanate (FITC)-labeled dextran (F-dextran) remained within injected mesophyll cell of a plant expressing TGB2 and TGB3 (line 12.42). B, Chlorophyll autofluorescence from same field of view presented in (A); injected cell outlined for orientation. C, The 10-kDa F-dextran moved from cell to cell when injected into a mesophyll cell of a plant expressing TGB1 (line 18.39). D, White clover mosaic potexvirus (WClMV) TGB1 potentiated limited movement (up to 7 cells) of 10-kDa F-dextran when co-injected into a mesophyll cell in a vector control transgenic plant (line $\mathrm{C}_{1}$ ). E, WCIMV TGB1 potentiated the extensive movement of 10-kDa F-dextran when co-injected into a mesophyll cell within a transgenic plant expressing both TGB2 and TGB3 (line 12.42). F, Chlorophyll autofluorescence from same field of view presented in (E); injected cell outlined for orientation. G, Cell-to-cell movement of 10-kDa Fdextran following its co-injection with WClMV mutant TGB1- $\Delta$ C protein. H, Containment of fluorescence associated with WClMV single-stranded (ss)RNA-TOTO in the injected cell following its co-injection with TGB1- $\Delta$ C protein. I, Cellular arrangement of mesophyll cells, from same field of view seen in $(\mathbf{H})$, gained by a second microinjection of Hoechst DNA-specific stain (33342) into a cell (identified by dart) adjacent to initial injection site. 
typical confocal laser scanning microscope (CLSM) image collected after 10-kDa F-dextran was microinjected into a mesophyll cell located within a plant line expressing both TGB2 and TGB3. Figure 3B depicts the general cellular arrangement of the mesophyll at the site of injection (red represents autofluorescence from chloroplasts). These results established that neither TGB2 nor TGB3, when expressed individually or together, has the capacity to increase plasmodesmal SEL. Additionally, these images confirm that the restriction of fluorescence within the microinjected cell shows that degradation of $10-\mathrm{kDa}$ F-dextran does not account for or contribute to the movement of fluorescence in this and subsequent experiments. This conclusion was supported by earlier studies in which $10-\mathrm{kDa}$ F-dextran was extracted from microinjected tissue and shown, by electrophoresis, to retain its original properties of molecular size and fluorescence (Wolf et al. 1989).

Expression in transgenic plants of the WCIMV TGB1 gave rise to an increase in plasmodesmal SEL. Figure 3C represents a confocal image collected 5 min after $10-\mathrm{kDa}$ F-dextran was microinjected into a mesophyll cell within a mature leaf of a transgenic plant expressing TGB1 (line 18.39). Note that fluorescence associated with the movement of the $10-\mathrm{kDa} F$ dextran can be detected in approximately 20 cells. Microinjection data presented in Table 2 demonstrate that the 10- and 20-kDa F-dextrans, but not the 40-kDa F-dextran, could move from cell to cell in these TGB1 transgenic plants. Thus, TGB1, produced in planta, has the capacity to interact with PD to induce an increase in SEL to a value greater than 20 but less than $40 \mathrm{kDa}$. Furthermore, these studies established that modification of plasmodesmal SEL is exclusively a function of TGB1 and not of either TGB2 or TGB3.

As the WCIMV CP is necessary for cell-to-cell spread (Forster et al. 1992), we next investigated whether it had the capacity to increase plasmodesmal SEL. Transgenic plants expressing the CP, in a background of both TGB2 and TGB3, were obtained by crossing the appropriate plant lines. (Expression of TGB2 and TGB3 in the progeny of this $F_{1}$ cross was confirmed by complementation. Presence of the $\mathrm{CP}$ was confirmed by immunoblot analysis with a CP-specific antisera [data not shown]). Results of microinjection experiments performed on these plants are presented in Table 2. These studies established that the 10-kDa F-dextran failed to move out of the injected mesophyll cell, and thus the WCIMV CP must be incapable of mediating an increase in plasmodesmal SEL.

\section{WCIMV TGB1 has the capacity to traffick through PD.}

A direct examination of the in vivo function of TGB1 was carried out with protein expressed in and extracted from $E$. coli. Purified TGB1 was FITC-labeled (TGB1-FITC) and then used in microinjection experiments. When introduced into a mesophyll cell within control plants (line $\mathrm{C}_{1}$ ), TGB1-FITC moved into neighboring cells within approximately $60 \mathrm{~s}$ and subsequently moved to the next cell layer within 2 to 4 min. The data presented in Table 3 illustrate that, in this experimental tissue, movement of fluorescence was detected in approximately $50 \%$ of the injections performed. Furthermore, when movement occurred, it was confined to 3 to 7 cells within the site of injection. As expected, based on experiments performed on transgenic plants expressing the TGB1, the TGB1 also potentiated the cell-to-cell movement of 10-kDa F- dextran when it was co-injected into mesophyll cells of control plants (Table 3, line $\mathrm{C}_{1}$ ). Figure 3D illustrates the limited cell-to-cell movement (approximately 7 cells) that took place when TGB1 and 10-kDa F-dextran were co-injected into a mesophyll cell within such a control plant. Limited cell-to-cell movement was also observed when TGB1 and 10-kDa Fdextran were co-injected into plants expressing either TGB2 or TGB3. Collectively, these data established that TGB1 is capable of limited movement between cells and that its ability to move is not influenced (enhanced) by the presence of either TGB2 or TGB3 when present alone.

In marked contrast to the above-described experiments, when TGB1 was microinjected into mesophyll cells within transgenic plants that expressed both TGB2 and TGB3, extensive cell-to-cell movement was detected. In Figure 3E we present a CLSM image illustrating the extensive nature (greater than approximately 40 cells) of TGB1 movement in plants expressing both TGB2 and TGB3. Fluorescence in Figure 3E reports the co-movement of $10-\mathrm{kDa}$ F-dextran during the trafficking of TGB1, while in Figure 3F chlorophyll autofluorescence has been used to illustrate the spatial distribution of mesophyll cells within the injected region of the leaf. A summary of our TGB1 injection studies is presented in Table 3. From such experiments it is clear that, for effective cell-to-cell movement, the WCIMV TGB1 requires the presence of both TGB2 and TGB3. Finally, it is important to note that, when microinjected into transgenic plants expressing the $\mathrm{CP}$ as well as TGB2 and TGB3, TGB1 was still able to move, thereby establishing that the $\mathrm{CP}$, although detected in $\mathrm{PD}$ of transgenic plants expressing CP (R. Forster and P. Sutherland, unpublished results), does not interfere with the capacity of TGB1 to traffick through PD.

Table 3. TGB1 interacts with plasmodesmata to potentiate its own cellto-cell movement in mesophyll cells of transgenic Nicotiana benthamiana plants

\begin{tabular}{|c|c|c|c|c|}
\hline \multirow[b]{2}{*}{$\begin{array}{l}\text { Transgenic } \\
\text { line }\end{array}$} & \multirow[b]{2}{*}{$\begin{array}{c}\text { Protein } \\
\text { expressed }^{\mathrm{a}}\end{array}$} & \multirow[b]{2}{*}{ Injected material } & \multicolumn{2}{|c|}{ Microinjections $^{\mathbf{b}}$} \\
\hline & & & $\begin{array}{l}\text { Total } \\
\text { (no.) }\end{array}$ & $\begin{array}{l}\text { Movement } \\
(\text { no. }[(\%])\end{array}$ \\
\hline $\mathrm{C}_{1}$ & - & TGB1-FITC & 10 & $5(50)$ \\
\hline $\mathrm{C}_{1}$ & - & $\begin{array}{c}\text { TGB } 1+10-\mathrm{kDa} F- \\
\text { dextran }\end{array}$ & 38 & $21(55)$ \\
\hline $10.3_{3}$ & TGB2 & $\begin{array}{c}\text { TGB } 1+10-k D a F- \\
\text { dextran }\end{array}$ & 20 & $8(40)$ \\
\hline $11.3_{1}$ & TGB3 & $\begin{array}{c}\text { TGB1 + 10-kDa F- } \\
\text { dextran }\end{array}$ & 29 & $15(52)$ \\
\hline $12.4_{2}$ & TGB $2+3$ & TGB1-FITC & 14 & $10(71)$ \\
\hline $12.4_{2}$ & TGB2+3 & $\begin{array}{l}\text { TGB1 + 10-kDa F- } \\
\text { dextran }\end{array}$ & 61 & 47 (77) \\
\hline $14.3_{1}$ & TGB2+3 & $\begin{array}{c}\text { TGB1 + 10-kDa F- } \\
\text { dextran }\end{array}$ & 27 & $19(70)$ \\
\hline $15.3_{2}$ & TGB $2 *+3$ & $\begin{array}{c}\text { TGB1 + 10-kDa F- } \\
\text { dextran }\end{array}$ & 19 & $15(79)$ \\
\hline $12.4_{2} \times \mathrm{S} 13$ & $\mathrm{TGB} 2+3+\mathrm{CP}$ & $\begin{array}{l}\text { TGB1 + 10-kDa F- } \\
\text { dextran }\end{array}$ & 23 & $16(70)$ \\
\hline
\end{tabular}

${ }^{a}$ White clover mosaic potexvirus (WCIMV) triple gene block protein (TGBP) expression by the transgenic plant was confirmed by complementation of WCIMV TGB mutants (see Table 1). Details for line $15.3_{2}$, expressing a mutant form of TGB2, are as described by Beck et al. (1994). Expression of the WClMV coat protein (CP) was confirmed by immunoblot analysis with a WClMV CP-specific antiserum.

${ }^{\mathrm{b}}$ Experimental details are as presented for Tables 1 and 2. Lucifer yellow $\mathrm{CH}(\mathrm{LYCH})$ and 10-kDa fluorescein isothiocyanate (FITC)-labeled dextran (F-dextran) controls are as presented in Table 2. 


\section{Reconstitution of WCIMV RNA movement by microinjection.}

Experiments were next performed to ascertain the viral constituents required for PD trafficking of WCIMV RNA. For control experiments, fluorescent TOTO-1 iodide-labeled transcripts of WCIMV (ss-RNA-TOTO) were injected into mesophyll cells within plants expressing both TGB2 and TGB3, as well as into cells expressing these same TGBPs plus the CP. In addition, injections of fluorescently labeled transcripts were also performed on transgenic plants expressing both TGB1 and the CP. As shown by the microinjection data presented in Table 4, when TOTO-labeled transcripts were introduced into mesophyll cells of each of the above-mentioned plant lines, fluorescence was confined to the injected cell.

In that some level of nucleic acid binding capacity appears to be important for effective MP-mediated, cell-to-cell transport of viral infectious material (Ghoshroy et al. 1997 and references therein), RNA gel mobility-shift assays were next performed with TGB1 preparations used in parallel microinjection experiments. In the presence of a low level of TGB1, the ss-RNA probe exhibited a dispersed mobility-shift pattern. Addition of increasing amounts of TGB1 to the ss-RNA probe resulted in the formation of a high-molecular-weight band (Fig. 4A, lanes 1-5). These studies indicated that the TGB1 binds noncooperatively to ss-RNA WCIMV. In view of this finding, we were surprised to discover that, unlike other viral MPs studied thus far, TGB1 did not mediate cell-to-cell transport of WCIMV ss-RNA-TOTO when co-injected into transgenic plants expressing TGB2 and TGB3 (Table 4).

To explore the basis for this unexpected finding, microinjection experiments were next performed in which we used the 10-kDa F-dextran to monitor the effect of TGB1 on plasmodesmal SEL. The data presented in Table 4 reveal that, in the presence of WCIMV ss-RNA, the ability of TGB1 to interact with PD to induce an increase in SEL was severely impaired (Table 4). Parallel experiments performed on transgenic plants expressing TGB2 and TGB3, plus the CP, revealed that, in this genetic background, TGB1 retained its capacity to in- duce an increase in PD SEL and mediate the cell-to-cell transport of WCIMV ss-RNA; fluorescence associated with the coinjected F-dextran moved out into the surrounding cells (Table 4).

Based on these experiments, it appeared that the $\mathrm{CP}$ in some way restored the capacity of TGB1 to interact with WCIMV ss-RNA and PD to permit cell-to-cell transport. This hypothesis was tested by microinjecting $\mathrm{CP}$ (purified from virions) and TGB1 together with WCIMV ss-RNA-TOTO (into cells expressing both TGB2 and TGB3). Co-injected CP restored the ability of TGB1 to interact with PD and potentiated cellto-cell movement of fluorescence associated with the WCIMV ss-RNA-TOTO (Table 4). It is important to stress that, in these experiments, fluorescence associated with TOTOlabeled RNA was detected in up to 15 cells from the site of injection. It is also important to note that identical results were obtained when the movement of ss-RNA was monitored by observing fluorescence associated with either chromatide fluorescein-12-UTP covalently incorporated into transcripts (CFUTP-labeled ss-RNA) or TOTO-labeled RNA. Finally, the data presented in Table 4 also confirm the equivalence of the findings obtained with F-dextran and TOTO-labeled RNA.

These experiments indicated that a complex, consisting of TGB1, ss-RNA, and the CP, may traffick through PD. Gel mobility-shift assays were next performed to ascertain whether the CP could interact with RNA and/or a TGB1-RNA complex. In the presence of a low level of $\mathrm{CP}$, a small fraction of the RNA probe underwent a mobility-shift consistent with cooperative binding by the $\mathrm{CP}$ (Fig. 4A, compare lanes 6 and 7). Addition of increasing amounts of $\mathrm{CP}$ to the ss-RNA probe resulted in the formation of a high-molecular-weight complex (Fig. 4A, lanes 8 and 9). These gel mobility-shift experiments established the TGB1 and CP threshold concentrations required for the formation of a high-molecular-weight proteinss-RNA complex. These conditions were then used in subsequent binding experiments. TGB1 and radioactively labeled RNA were incubated for $10 \mathrm{~min}$ at room temperature prior to the addition of CP. These experiments indicated that increas-

Table 4. Reconstitution of white clover mosaic potexvirus (WCIMV) RNA movement in mesophyll tissue of transgenic Nicotiana benthamiana plants ${ }^{\mathrm{a}}$

\begin{tabular}{|c|c|c|c|c|}
\hline \multirow[b]{2}{*}{ Transgenic line } & \multirow[b]{2}{*}{ Protein expressed } & \multirow[b]{2}{*}{ Injected material } & \multicolumn{2}{|c|}{ Microinjections } \\
\hline & & & Total (no.) & Movement (no. [\%]) \\
\hline $12.4_{2}$ & TGB2+3 & WCIMV ss-RNA-TOTO ${ }^{\mathrm{b}}$ & 16 & $2(13)$ \\
\hline $18.3_{2} \times \mathrm{S} 13$ & $\mathrm{TGB} 1+$ coat protein $(\mathrm{CP})$ & WCIMV ss-RNA-TOTO & 12 & $0(0)$ \\
\hline $12.4_{2} \times \mathrm{S} 13$ & $\mathrm{TGB} 2+3+\mathrm{CP}$ & WClMV ss-RNA-TOTO & 16 & $2(13)$ \\
\hline 12.4 & TGB2+3 & sWCIMV ss-RNA-TOTO + TGB1 & 18 & $3(17)$ \\
\hline $12.4_{2}$ & TGB2+3 & WClMV ss-RNA + TGB1 + 10-kDa F-dextran ${ }^{\mathrm{c}}$ & 22 & $5(23)$ \\
\hline $12.4_{2} \times \mathrm{S} 13$ & $\mathrm{TGB} 2+3+\mathrm{CP}$ & WCIMV ss-RNA + TGB1 + 10-kDa F-dextran & 15 & $11(73)$ \\
\hline $12.4_{2}$ & TGB $2+3$ & WCIMV ss-RNA-TOTO + TGB $1+$ CP $^{\mathrm{d}}$ & 16 & $11(69)$ \\
\hline $12.4_{2} \times \mathrm{S} 13$ & $\mathrm{TGB} 2+3+\mathrm{CP}$ & WCIMV ss-RNA-TOTO + TGB1 & 25 & $16(64)$ \\
\hline $12.4_{2} \times \mathrm{S} 13$ & $\mathrm{TGB} 2+3+\mathrm{CP}$ & MS2 ss-RNA-TOTO + TGB1 & 19 & $14(74)$ \\
\hline $12.4_{2}$ & TGB $2+3$ & TGB1- $\Delta \mathrm{C}^{\mathrm{f}}+10-\mathrm{kDa}$ F-dextran & 19 & $12(63)$ \\
\hline $12.4_{2} \times \mathrm{S} 13$ & $\mathrm{TGB} 2+3+\mathrm{CP}$ & WCIMV ss-RNA-TOTO + TGB $1-\Delta C$ & 16 & $4(25)$ \\
\hline $12.4_{2}$ & TGB2+3 & TGB1-GKS ${ }^{\mathrm{f}}+10-\mathrm{kDa}$ F-dextran & 19 & $8(42)$ \\
\hline $12.4_{2} \times \mathrm{S} 13$ & $\mathrm{TGB} 2+3+\mathrm{CP}$ & WCIMV ss-RNA-TOTO + TGB1-GKS & 16 & $6(38)$ \\
\hline $12.4_{2}$ & TGB2+3 & TGB1-ER ${ }^{\mathrm{f}}+10-\mathrm{kDa}$ F-dextran & 19 & $13(68)$ \\
\hline $12.4_{2} \times \mathrm{S} 13$ & $\mathrm{TGB} 2+3+\mathrm{CP}$ & WCIMV ss-RNA-TOTO + TGB1-ER & 14 & $11(79)$ \\
\hline
\end{tabular}

\footnotetext{
${ }^{\mathrm{a}}$ Experimental details are as given in Tables 1 and 2.

${ }^{\mathrm{b}}$ WCIMV single-stranded (ss) RNA labeled with TOTO-1.

${ }^{c}$ Fluorescein isothiocyanate (FITC)-labeled dextran (F-dextran).

${ }^{\mathrm{d}}$ WCIMV CP purified from virions.

e Bacteriophage MS2 ss-RNA as supplied commercially (Boehringer Mannheim, Indianapolis, IN).

${ }^{\mathrm{f}}$ TGB1 mutants as described in Figure 6.
} 
ing the amount of $\mathrm{CP}$ in the reaction mixture caused a significant increase in retardation of the TGB1-RNA complex (Fig. $4 \mathrm{~B}$, lanes 1-5). Reversing the order of binding gave the same result (Fig. 4B, lanes 6-9). Thus, these gel mobility-shift assays yielded results consistent with the in vitro formation of a TGB1-RNA-CP complex.

The first 50 nucleotides of the potexvirus genome are thought to encode the viral origin of assembly (OAS) for particle formation (Sit et al. 1994). Results of binding studies
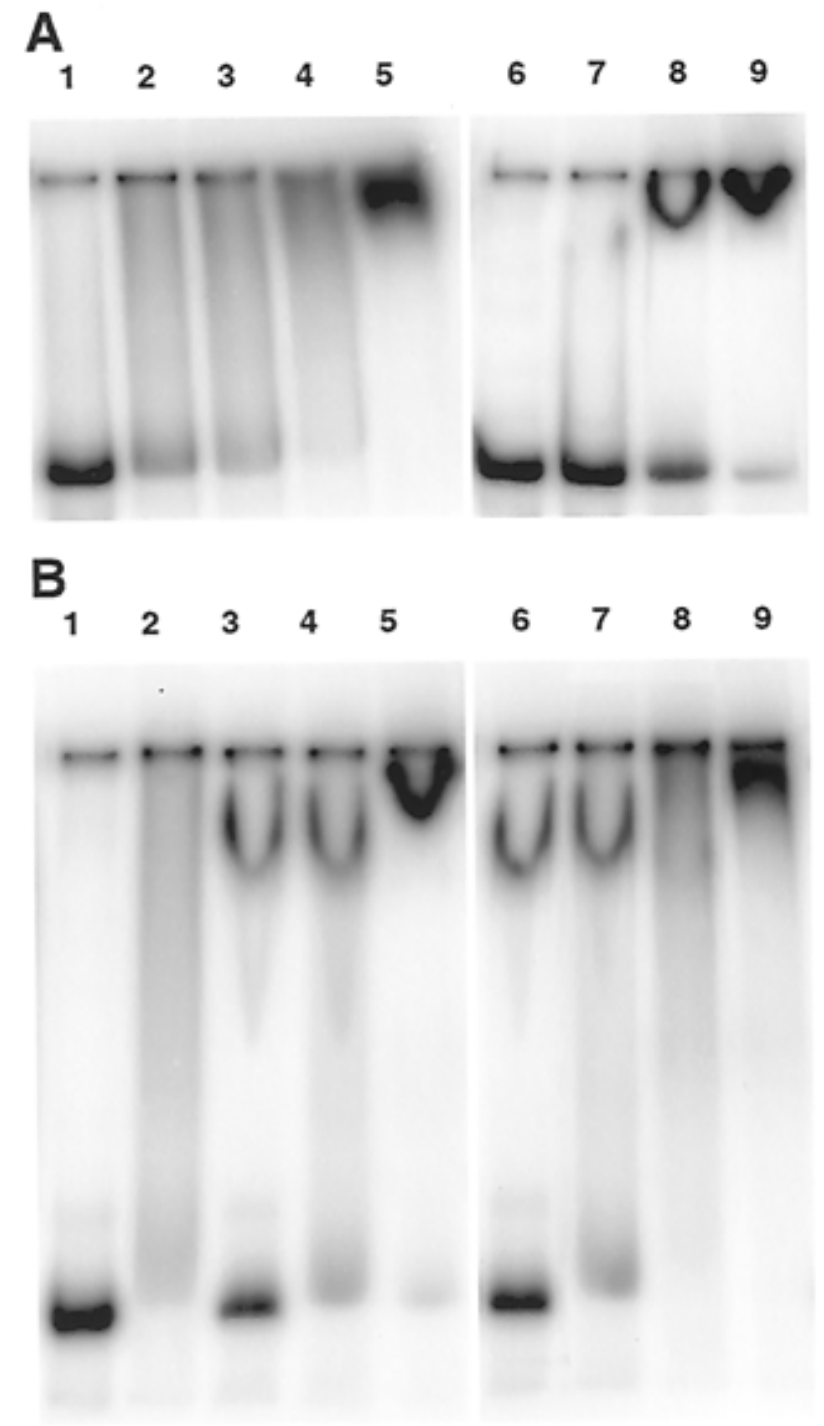

Fig. 4. In vitro RNA binding gel mobility-shift assays. A, Prior to electrophoresis, on a $5 \%$ polyacrylamide gel, an $\left[\alpha{ }^{32} \mathrm{P}\right]-$ UTP-labeled transcript of the $5^{\prime}$ terminal 450 nucleotides of white clover mosaic potexvirus (WCIMV) was incubated with Escherichia coli-expressed TGB1 or virion-purified coat protein $(\mathrm{CP})$ at room temperature for $10 \mathrm{~min}$ in 10 $\mu 1$ of buffer. Lanes $1-5$, probe incubated with $0.3,0.6,1.2,2.5$, and $5 \mu \mathrm{g}$ of TGB1, respectively. Lane 6, radiolabeled probe. Lanes 7-9, probe incubated with $0.3,0.6$, and $1.2 \mu \mathrm{g} \mathrm{CP}$, respectively. B, TGB1/CP and $\left[\alpha-{ }^{32} \mathrm{P}\right]-$ UTP-labeled transcript incubated at room temperature for 10 min in buffer prior to addition of CP/TGB1 and electrophoresis (as in A). Lane 1, radiolabeled probe. Lanes 2-9, probe incubated with $1.0 \mu \mathrm{g}$ of TGB1, $0.8 \mu \mathrm{g}$ of CP, $1.0 \mu \mathrm{g}$ of TGB1 $+0.8 \mu \mathrm{g}$ of CP, $1.0 \mu \mathrm{g}$ of TGB1 $+1.6 \mu \mathrm{g}$ of CP, $0.8 \mu \mathrm{g}$ of $\mathrm{CP}, 0.8 \mu \mathrm{g}$ of $\mathrm{CP}+1.0 \mu \mathrm{g}$ of TGB $1,0.8 \mu \mathrm{g}$ of $\mathrm{CP}+2.0 \mu \mathrm{g}$ of TGB1, $0.8 \mu \mathrm{g}$ of $\mathrm{CP}+4.0 \mu \mathrm{g}$ of TGB1, respectively. conducted with an RNA probe containing this putative OAS were identical to those performed with a probe that lacked the OAS (data not shown). These experiments established that RNA binding, by the CP, is not sequence specific. Furthermore, experiments in which bacteriophage MS2 ss-RNATOTO (Fiers et al. 1976) was co-injected with TGB1 into transgenic plants expressing the $\mathrm{CP}$, TGB2, and TGB3 resulted in TGB1-mediated RNA trafficking (Table 4). This result established also that, under the conditions of these experiments, (i) potexvirus sequences are not required for TGB1-mediated, cell-to-cell transport of RNA, and (ii) virion formation is not involved as a step in this RNA trafficking process.

To further test the hypothesis that the WCIMV RNA moves through PD as a TGB1-ss RNA-CP complex, microinjection experiments were performed in which a combination of fluorescently labeled probes were introduced into mesophyll cells of $N$. benthamiana. Ideally, co-injection experiments in which TGB1, CP, and ss-RNA were all independently labeled would have allowed us to simultaneously monitor the cell-to-cell movement of the three constituents of the putative infectious complex. Unfortunately, chlorophyll autofluorescence within the mesophyll prevented the use of fluorescent probes in the 630 to $700 \mathrm{~nm}$ region. However, by using a combination of CFUTP-labeled ss-RNA and cyanine-3.5 dye (CY3.5)-labeled TGB1/CP, along with unlabeled TGB1/CP, we were able to collect evidence fully consistent with the above hypothesis.

Representative data from these co-injection experiments are presented in Figure 5. Evidence that CY3.5-labeled CP moves from cell to cell, along with the CF-UTP ss-RNA and unlabeled TGB1, is presented in Figure 5A and B. Direct evidence that the CF-UTP ss-RNA moves cell to cell with the CY3.5labeled TGB1, plus the unlabeled CP, is presented in Figure $5 \mathrm{C}$ and $\mathrm{D}$. The absolute requirement for TGB 1 is again demonstrated by the image presented in Figure 5E, in which $\mathrm{CF}$ -

Fig. 5. Simultaneous cell-to-cell trafficking of fluorescently labeled TGB1, single-stranded (ss) RNA, and coat protein (CP) following coinjection into Nicotiana benthamiana mesophyll cells. Details relating to microinjection experiments and imaging via confocal laser scanning microscopy (CLSM) are as in Figure 3. White clover mosaic potexvirus (WCIMV) CP and TGB1 were labeled with cyanine-3.5 dye (CY3.5), whereas ss-RNA was labeled with chromatide fluorescein (CF)-UTP. Microinjection experiments were performed on mesophyll cells (arrowed) within transgenic plants that expressed WCIMV TGB2 and TGB3 (line 12.4 $4_{2}$. (Scale bars represent $100 \mu \mathrm{m}$.) A, Cell-to-cell movement of CF-UTP-labeled ss-RNA potentiated by its co-injection into the cell along with CY3.5-labeled CP and unlabeled TGB1. B, Fluorescence associated with movement of CY3.5-labeled CP following its co-injection with CF-UTP-labeled ss-RNA and unlabeled TGB1. Images in $\mathbf{A}$ and $\mathbf{B}$ were collected simultaneously with the CLSM CF-UTP and CY3.5 channels, respectively. C, Cell-to-cell movement of CF-UTPlabeled ss-RNA following its co-injection with CY3.5-labeled TGB1 and unlabeled CP. D, Fluorescence associated with movement of CY3.5labeled TGB1 following its co-injection with CF-UTP-labeled ss-RNA and unlabeled CP. Images in $\mathbf{C}$ and $\mathbf{D}$ were collected simultaneously with the CLSM CF-UTP and CY3.5 channels, respectively. Fluorescence associated with (E) CF-UTP-labeled ss-RNA that was co-injected into the cell with unlabeled CP, or with Cy3.5-labeled CP that was (F) co-injected into the cell with unlabeled TGB1 or (G) microinjected, alone, into a mesophyll cell. 
UTP-labeled RNA and CP were unable to move beyond the injected cell (compare Figure 5E to Figure 5A and B). (This restriction of fluorescence within the microinjected cell shows that degradation of CF-UTP ss-RNA does not account for or contribute to the movement of fluorescence in this and subsequent experiments.) Furthermore, the inability of CY3.5labeled CP to move when injected alone (Fig. 5G) or when co- injected with TGB1 (Fig. 5F) indicated that the cell-to-cell spread of fluorescence illustrated in Figure 5B must reflect an interaction between the CF-UTP-labeled ss-RNA, TGB1 (unlabeled) and the CY3.5-labeled CP.

Analysis of the spatial distribution of fluorescence, associated with both the CF-UTP-labeled ss-RNA and CY3.5labeled protein (TGB1 or $\mathrm{CP}$ ), within the injected tissues gen-
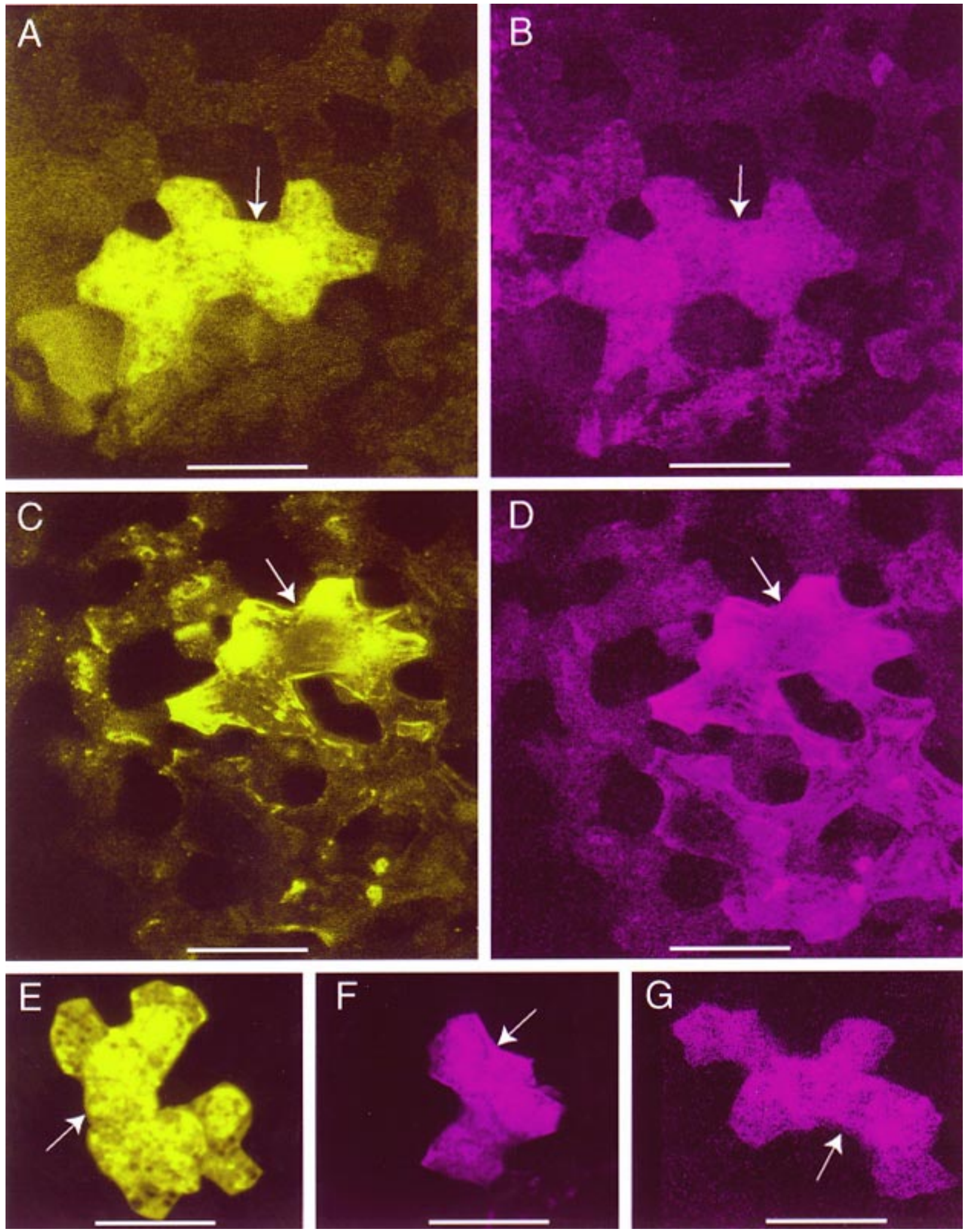
erally revealed a high degree of coincidence between the relative intensities of each probe. A few minor differences in fluorescence intensities were noted during these experiments, which may reflect small changes in the in vivo stoichiometry between the TGB1, CP, and RNA. In any event, these observations are consistent with the presence of a complex in which the fluorescence signals, associated with both the RNA and TGB1/CP, move through a number of cellular boundaries. Thus, the experimental evidence presented in Figure 5 indicates that, after microinjection, a complex composed of fluorescently labeled proteins and ss-RNA trafficks through PD.

Collectively, the complementation, microinjection, and gel mobility-shift studies establish that TGB1 requires the presence of the CP, in addition to TGB2 and TGB3, to carry out efficient cell-to-cell transport of WCIMV ss-RNA. These data are fully consistent with the requirements for cell-to-cell movement of potexviruses deduced from viral infection studies (Beck et al. 1991; Chapman et al. 1992; Forster et al. 1992; Baulcombe et al. 1995). Additionally, these findings are also consistent with trans-complementation experiments, performed with PVX, that suggested the co-movement of TGB1 and PVX RNA (Morozov et al. 1997). Finally, the data presented in Figure 5 provide strong support for the hypothesis that potexvirus cell-to-cell spread occurs through plasmodesmal trafficking of a TGB1-ss-RNA-CP complex.

To further explore the function of TGB1 in viral RNA transport, specific mutations were engineered in regions of these proteins known to be highly conserved between the potex-, carla-, benya-, and hordeivirus groups. Figure 6 documents the sites and nature of the mutations that were engineered in TGB1. Deletion of 32 amino acids from the TGB1 $\mathrm{C}$ terminus (effectively deleting domain VI of the putative helicase) (Habili and Symons 1989) had a detectable effect on its ability to traffick from cell to cell. As illustrated in Figure $3 \mathrm{G}$, co-injection of TGB $1-\Delta \mathrm{C}$ and $10-\mathrm{kDa}$ F-dextran, into mesophyll cells expressing TGB2 and TGB3, resulted in movement into approximately 20 cells. Comparing the extent of movement depicted in Figure 3E (wild-type TGB1) and Figure $3 \mathrm{G}$ underscores that, while movement of TGB1- $\Delta \mathrm{C}$ could mediate movement of the $10-\mathrm{kDa}$ F-dextran, it appeared to be about half as effective as that mediated by the wild-type protein. In addition, Figure $3 \mathrm{H}$ demonstrates that WClMV ssRNA-TOTO remained within the mesophyll cell (expressing TGB2, TGB3, and CP) when co-injected with TGB1- $\Delta \mathrm{C}$ (arrangement of surrounding cells illustrated in Figure 3I). The inability of this $\Delta \mathrm{C}$ mutant to traffick RNA suggests that RNA helicase activity may be required for RNA trafficking, or that domain VI is required for RNA binding (Fernandez et al. 1995). Alternatively, the $C$ terminus of TGB1 may be required to interact with an additional protein component to facilitate RNA transport. Gel mobility-shift assays demonstrated that RNA binding was not abolished by the C-terminal truncation (data not shown), indicating that domain VI is not the only domain involved in RNA binding.

The data presented in Table 4 indicate that the mutations, made within charged amino acid residues $\mathrm{N}$-terminal of domain VI of the WCIMV TGB1 (TGB1-ER), had no detectable effect on the ability of the mutant protein to mediate its own cell-to-cell trafficking, nor on its capacity to transport WCIMV ss-RNA-TOTO through PD.

The requirement of the ATPase function associated with domain I of TGB1 was probed with the GKS mutant (TGB1GKS) (Fig. 6). Experiments conducted on transgenic plants expressing this GKS mutation (line 16.3 ) indicated that, compared with wild type, it had a reduced ability to increase plasmodesmal SEL (Table 2). Consistent with this finding, the GKS mutant also displayed a reduced ability to traffick cell to cell, in that the frequency with which it moved in injection experiments was lower compared with wild-type protein (42 and $77 \%$, respectively; compare Tables 3 and 4). Furthermore, as with TGB1- $\Delta \mathrm{C}$, the extent of protein-mediated F-dextran movement was also reduced, with fluorescence being restricted to within the immediate vicinity of the injected cell (3 to 5 cells). However, in contrast to the situation observed for the $\Delta \mathrm{C}$ mutant, the frequency and extent of TGB1-GKSmediated WCIMV ss-RNA-TOTO transport was equivalent to that detected with F-dextran (Table 4). These experiments indicate that the ATPase function of TGB1 appears to influence the efficacy with which this protein interacts with the cellular constituents involved in PD macromolecular trafficking.

Our data support the hypothesis that WCIMV RNA moves through PD as a TGB1-ss-RNA-CP complex. However, all

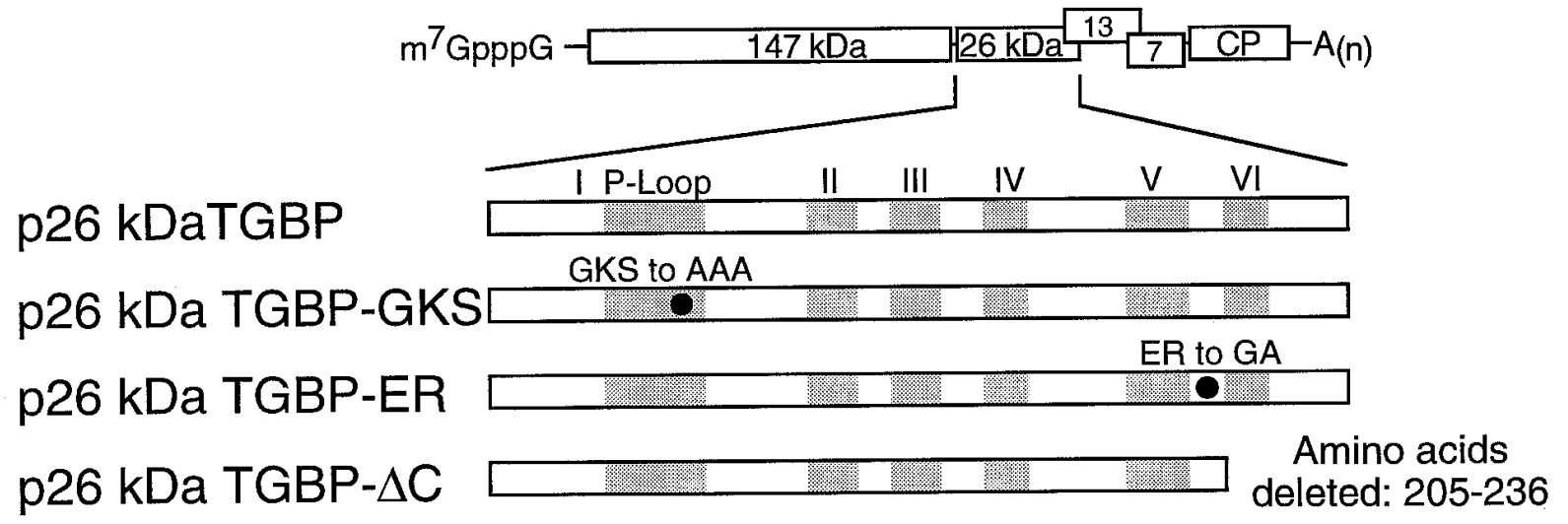

Fig. 6. Cloning and mutagenesis of the TGB1 open reading frame (ORF) for expression in Escherichia coli. Position of TGB1 ORF in the white clover mosaic potexvirus (WClMV) genome is indicated. Helicase motifs I to VI are identified by shading and site of ATP binding motif (P-loop) is indicated. Wild-type TGB1 ORF was modified with oligonucleotide-directed mutagenesis to produce mutants $\mathrm{TGB}^{-\mathrm{GKS}}\left(\mathrm{G}_{33}-\mathrm{K}_{-} \mathrm{S}_{35}\right.$ changed to $\left.\mathrm{A}_{33}-\mathrm{A}-\mathrm{A}_{35}\right)$, TGB1-ER ( $\mathrm{E}_{207}-\mathrm{E}-\mathrm{E}-\mathrm{R}_{210}$ changed to $\mathrm{E}_{207}-\mathrm{E}-\mathrm{G}-\mathrm{A}_{210}$ ), and TGB1- $\Delta \mathrm{C}$ (stop codon introduced following $\mathrm{I}_{204}$ to delete the $\mathrm{C}$-terminal 31 amino acid residues). 
attempts to reconstitute this system by microinjection of WCIMV ss-RNA-TOTO into cells expressing both the CP and TGB1 failed to yield movement of fluorescence into the surrounding cells (Table 4). This finding underscores the essential function(s) played by TGB2 and TGB3 in RNA trafficking. The equivalent TGBPs from other TGB-containing viruses are considered to be membrane associated (Morozov et al. 1990; Niesbach-Klosgen et al. 1990; Donald et al. 1993; Hefferon et al. 1997). Insight into the mechanism by which TGB2 might function was gained by experiments in which a dysfunctional form of this protein (along with the wild-type TGB3) was expressed in transgenic plants (Beck et al. 1994). This mutant TGB2 (a conserved motif $\mathrm{G}_{48}-\mathrm{G}-\mathrm{G}-\mathrm{Y}-\mathrm{K}-\mathrm{D}-\mathrm{G}-\mathrm{T}_{55}$ within a central hydrophilic region was changed to $\mathrm{A}_{48}-\mathrm{A}-\mathrm{E}-$ $\mathrm{F}-\mathrm{K}-\mathrm{A}-\mathrm{A}-\mathrm{A}_{55}$ ) acted to severely impede the spread within the inoculated leaf of wild-type WClMV. Microinjection studies performed on these same plants (line 15.32) (Beck et al. 1994) revealed that TGB1 could traffick, from cell to cell, in a manner identical to that observed on plants expressing wild-type TGB2 and TGB3 (Table 3). Thus, the conserved hydrophilic region within TGB2 appears to be involved solely with the trafficking of TGB1-ss-RNA-CP complex.

\section{DISCUSSION}

In this study, we present evidence that each of the WCIMV TGB mutants could be rescued by complementation with transgenic plants expressing specific TGBPs. Complementation studies showed that TGB functions can be fulfilled in trans. Hence, it would appear that there are no specific requirements for the coordinate temporal/spatial expression of these TGBPs within mesophyll cells of $N$. benthamiana for the efficient movement of viral RNA. Direct evidence is presented showing that TGB1 can induce an increase in SEL and mediate its own cell-to-cell transport, via mesophyll PD. In addition, provided injections are performed into cells having the correct genetic background (i.e., into cells expressing TGB2, TGB3, and the CP), TGB1 can potentiate the cell-tocell spread of RNA. As these properties parallel those previously characterized for a number of viral MPs, our studies thus establish that the WCIMV TGB1 functions as a viral MP.

In marked contrast to other previously characterized viral MPs, TGB1 appears to be unique in that efficient cell-to-cell transport requires the presence of additional viral-encoded proteins, namely, TGB2 and TGB3. This conditional requirement applied equally to the situation in which TGB1 moved alone, or in combination with the WCIMV ss-RNA. The explicit mechanism by which TGB2 and TGB3 facilitate efficient cell-to-cell transport remains to be elucidated (see below).

The CP is also required for cell-to-cell trafficking of potexvirus RNA (Chapman et al. 1992; Forster et al. 1992; Baulcombe et al. 1995). Our results now provide a cellular basis to explain this requirement. TGB1 cannot transport WClMV RNA transcript in the absence of CP. The basis for this $\mathrm{CP}$ requirement is explained by the inability of TGB1 to increase PD SEL in the presence of ss-RNA. In this situation, the CP has the capacity to interact with either TGB1, the RNA, or both, to restore the ability of such a complex to increase SEL and support RNA transport. Indeed, the current experiments in which we employed a combination of fluorescently labeled RNA, TGB1, CP, and CLSM provide direct and compelling evidence that a viral ribonucleoprotein complex (vRNc), consisting of TGB1, WCIMV ss-RNA, and the CP, moves through PD of mesophyll expressing TGB2 and TGB3. A logical extension from these findings is that, during the infection process, WCIMV moves cell to cell within tissues as a TGB1-ss-RNA-CP complex. Such a complex may move through a number of cells without a requirement for replication. This may account for the observations of Angell and Baulcombe (1995) that PVX, tagged with a GUS reporter, was apparently capable of accumulating along the leaf margin in some but not all intervening cells (as judged by the absence of GUS activity in intervening cells).

The observation that fluorescence associated with WCIMV RNA moved into neighboring cells within seconds makes a requirement for virion formation, during RNA cell-to-cell transport, unlikely but not impossible. But MS2 ss-RNA, which lacks a WCIMV OAS for particle formation, still underwent TGB1-mediated plasmodesmal transport (within cells expressing TGB2 and TGB3 plus the CP), which supports the hypothesis that encapsidation is not involved. Furthermore, immunodetection of CP within PD of potexvirus-infected cells (Rouleau et al. 1995; Oparka et al. 1996; R. Forster and P. Sutherland, unpublished results) is fully consistent with the data presented in the present study. However, although seemingly inconsistent with our PD SEL data, the possibility cannot be discounted that infectious transcripts of WCIMV move cell to cell via two processes; one involving a vRNc, and a second in which virus particles move by a mechanism yet to be elucidated. This latter possibility could be tested by engineering mutant viruses that are unable to form virions.

Based on knowledge gained from these studies, a model is presented in Figure 7 to explain the cellular basis for the roles played by TGB1, the CP, TGB2, and TGB3 in mediating cellto-cell transport of WCIMV RNA. We have incorporated into this model the possibility that intracellular transport and delivery of WCIMV RNA involves the plant cytoskeleton. This aspect draws upon recent findings in which it was shown that the TMV MP co-localized with microtubules (Heinlein et al. 1995; McLean et al. 1996; Padgett et al. 1996). A vRNc of TGB1-WCIMV ss-RNA-CP forms within the infected cell and is delivered, via the cytoskeleton, to the PD orifice. Two possible functions of TGB2 and TGB3 are proposed: (i) to mediate in the delivery of the $\mathrm{vRNc}$, to a putative docking protein; or (ii) to function as part of a membrane-associated linker complex to deliver the vRNc, via the cytoskeleton, to the docking protein. The net effect is the efficient delivery of the $\mathrm{vRNc}$ to a docking protein at the PD orifice, with the subsequent transport of vRNc to the neighboring cell.

\section{MATERIALS AND METHODS}

Viral isolate, DNA cloning, primers, and plasmids.

WCIMV strain O was maintained and virions were purified as described by Beck et al. (1994). All DNA manipulations were performed by standard techniques (Sambrook et al. 1989). The construction of viral mutant clones p26a, p26c, p13a, and p13b has been described previously (Beck et al. 1991). Mutant p13KGUS was produced by inserting a polylinker at an EcoRI site of p13b (position 4833). The $E$. coli UidA gene coding sequence (GUS) was amplified by PCR with plasmid p263 (kindly provided by R. C. Gardner) as 
template. The resulting fragment, approximately $1,800 \mathrm{bp}$ in size, was digested with $\mathrm{NcoI}-\mathrm{BamHI}$ and then cloned into the p13b-polylinker digested with the same enzymes. Mutant p7c contained a mutation that modified TGB3 residue $G_{34}$ to $E_{34}$. Mutant p7c was produced with oligonucleotides in a PCR. This fragment was cloned into pWCIMV-4.

WCIMV TGB1 wild-type and mutant coding sequences were cloned into pET-3a (Studier et al. 1990) for expression in E. coli BL21::DE3 (see Figure 6). TGB1 coding sequence with NdeI at its initiation codon and BamHI at the $3^{\prime}$ end was generated by PCR. This fragment was cloned into NdeIBamHI cleaved pET-3a to create pTGB1. A modified TGB1 coding sequence (designed to produce a 32 amino acid Cterminally truncated protein product) with $\mathrm{NdeI}$ at its initiation codon and BamHI at the $3^{\prime}$ end was generated by PCR. This fragment was cloned into NdeI-BamHI-cleaved pET-3a to create pTGB1- $\Delta \mathrm{C}$. The coding sequence of the wild-type TGB1 sequence cloned into pET-3a was also modified to produce clones pTGB1-GKS and pTGB1-ER. All site-directed mutations were generated by oligonucleotide-directed mutagenesis according to the manufacturer's instructions (Morph kit, 5 prime 3 prime, Boulder, $\mathrm{CO}$ ).

WCIMV-O sequences representing wild-type CP, wild-type TGB, and mutated TGB sequences were amplified by PCR and subcloned into pSP72 (Promega, Madison, WI). An XbaI-

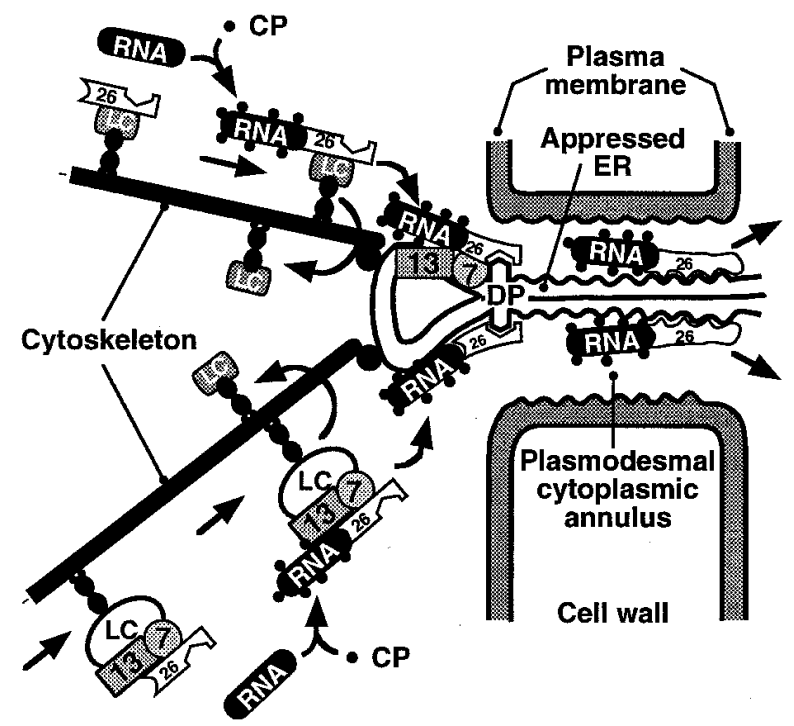

Fig. 7. Model for TGB1-mediated cytoplasmic and plasmodesmal transport of viral ribonucleoprotein complex (vRNc). Effective cell-to-cell movement of white clover mosaic potexvirus (WCIMV) RNA involves coordinate transport via the cytoskeleton and plasmodesmata (PD). TGB1 is shown interacting with the cytoskeleton either directly, through a host-encoded linker complex (LC, vesicle or special protein), or indirectly, via an interaction with TGB2 and TGB3. Non-sequence-specific binding of single-stranded (ss) RNA plus coat protein (CP) to the anchored TGB1 allows delivery of TGB1-viral RNA-CP (vRNc) to a putative plasmodesmal docking protein (DP) located within plasmodesmal orifice (shown as integral protein within the appressed endoplasmic reticulum [ER] but could also be located in the plasma membrane). An alternate function for TGB2 and TGB3 is presented in which both proteins function, as a membrane-located (ER or plasma membrane) heterodimer, to bind and deliver the $\mathrm{vRNc}$ to the plasmodesmal DP. Either site of action for TGB2 and TGB3 is consistent with the experimentally documented requirement for both proteins to be present within the mesophyll cell for vRNc transport through PD.
XhoI fragment containing the WCIMV sequence was cloned into pART7/pART27 (Gleave 1992). Binary vectors were constructed for transformation of $N$. benthamiana.

\section{Expression of WCIMV TGBPs in transgenic plants.}

WCIMV TGB and CP coding sequences were subcloned into the binary vector pART27 (Gleave 1992) and introduced into $N$. benthamiana by Agrobacterium tumefaciens-mediated leaf-disk transformation (Horsch et al. 1985). As illustrated in Figure 1B, transformants were regenerated that expressed either individual or specific combinations of WCIMV TGB ORFs. Seed from selected transformed lines was allowed to self-pollinate and homozygous seed from $\mathrm{T}_{2}-\mathrm{T}_{5}$ progeny was used throughout this study.

A single plant line, designated $12.4_{2}$, was regenerated following the introduction of the entire WCIMV TGB coding sequence into $N$. benthamiana. Sequence analysis of the original construct identified a mutation (ATG to TCC) that removed the initiation codon of TGB1 ORF but left intact TGB2 and TGB3 ORFs. A total of 19 independent transformants were regenerated and designated as plant lines $14.3_{1-19}$ from a construct designed to express the WCIMV TGB2 and TGB3 coding sequences. A total of 7 and 8 plant lines, designated $10.3_{1-7}$ and $11.3_{1-8}$, were regenerated following the introduction of TGB2 and TGB3 coding sequences, respectively, as monocistronic transgenes. A total of 15 plant lines, including line S13 described in this study, were regenerated following the introduction of the CP coding sequence into $N$. benthamiana (R. S. L. Forster, T. J. Lough, D. L. Beck, K. R. Hofstra, and E. Balmori, unpublished results). Plants expressing TGB2 and TGB3 as well as the CP were generated by crossing homozygous $\mathrm{T}_{5}$ progeny of plant line $\mathrm{S} 13$ (a CPexpressing plant line) with homozygous $\mathrm{T}_{3}$ plant line $12.4_{2}$ (expressing TGB2 and TGB3).

\section{Analysis of transgenic plants by complementation.}

Transcription reactions were performed as previously described (Beck et al. 1990). Plants were mechanically inoculated with $25 \mu \mathrm{l}$ of inoculum at concentrations of $50 \mu \mathrm{g}$ of RNA per ml as described by Beck et al. (1994). Northern and immunoblot analyses of uninoculated and inoculated leaves were performed by standard techniques (Sambrook et al. 1989; Beck et al. 1994). Histochemical assays for GUS activity were performed as described by Jefferson (1987). Serumspecific electron microscopy was performed with WCIMV CPspecific antisera. Briefly, grids were inverted on $0.1 \mathrm{mg}$ of protein-A per $\mathrm{ml}$ dissolved in phosphate-buffered saline (PBS) for $10 \mathrm{~min}$, drained to remove excess liquid, then inverted on $\mathrm{CP}$ specific antisera at 1:50 dilution. Grids were washed with PBS, inverted onto a crude plant sap extract, and incubated for 30 min. After being washed with PBS, the grids were stained with $1.5 \%$ phosphotungstate and observed through a JOEL JEM$1200 \mathrm{II}$ transmission electron microscopy operated at $80 \mathrm{kV}$.

\section{Protein expression, purification, and microinjection.}

TGB1 wild-type and mutant proteins were expressed with the E. coli strain BL21::DE3 as described by Noueiry et al. (1994). Both full-length infectious WClMV ss-RNA transcripts and bacteriophage MS2 ss-RNA (Boehringer Mannheim, Indianapolis, IN) used in microinjection experiments, at concentrations from 6 to $10 \mu \mathrm{g} / \mu \mathrm{l}$, were labeled with the nu- 
cleotide-specific stain TOTO-1 as described by Fujiwara et al. (1993). In some experiments, transcripts were covalently labeled by incorporation of chromatide fluorescein (CF)-12UTP according to the manufacturer's instructions (Molecular Probes, Eugene, OR). WCIMV CP used in microinjection experiments was purified from WCIMV virions. Briefly, 5 to 10 $\mathrm{mg}$ of virions was dialyzed against $0.1 \mathrm{M}$ sodium carbonate ( $\mathrm{pH} 10.5$ ) for 2 days at $4^{\circ} \mathrm{C}$. The contents of the dialysis bag were centrifuged at $105,000 \times g$ for $2 \mathrm{~h}$ to remove undecomposed virus. The supernatant was precipitated by adding an equal volume of saturated ammonium sulfate and again centrifuged at $105,000 \times g$ for $10 \mathrm{~min}$. The pellet was resuspended in water and precipitated with a half-volume of ammonium sulfate. The precipitate was pelleted, as above, and then dialyzed for $24 \mathrm{~h}$ against native buffer (Noueiry et al. 1994) with several changes. CP was used in microinjection experiments at a concentration of 1 to $3 \mathrm{mg} / \mathrm{ml}$. Fluorescent labeling of $\mathrm{CP}$ was achieved with a mono-functional cyanine dye (CY3.5; absorption and emission maxima at 581 and $596 \mathrm{~nm}$, respectively) following the manufacturer's instructions (Amersham, Piscataway, NJ). CY3.5-labeled CP was separated from excess unconjugated dye by size exclusion chromatography with prepacked Sephadex G-25 columns (PD-10, Pharmacia Biotech, Piscataway, NJ). Conjugation of CY3.5 to the WCIMV $\mathrm{CP}$ was confirmed to have no effect on the ability of the $\mathrm{CP}$ to interact with the TGB1-ss-RNA complex in gel mobility-shift assays.

The wild-type and mutant forms of TGB1 were produced in and then extracted from $E$. coli inclusion bodies by the procedures previously described (Noueiry et al. 1994). Extracted protein was stored in buffer $(10 \mathrm{mM}$ Tris- $\mathrm{HCl}, \mathrm{pH} 8.0,1 \mathrm{mM}$ EDTA, $10 \%$ [vol/vol] glycerol, and $200 \mathrm{mM} \mathrm{NaCl}$ ) with stock concentrations of between 1 and $3 \mathrm{mg} / \mathrm{ml}$. Labeling of TGB1 with FITC was performed by the method of Noueiry et al. (1994). Labeling of TGB1 with CY3.5 and subsequent removal of unconjugated dye were carried out with the same protocol followed for dye-labeling of the CP. Hoeschst DNA (nuclear) stain 33342 was obtained from Molecular Probes and a $1 \mathrm{mg} / \mathrm{ml}$ buffered solution was used in injection studies. Microinjection experiments were performed essentially as described by Wolf et al. (1989) with modifications by Lucas et al. (1995).

\section{In vitro RNA binding gel mobility-shift assays.}

The infectious transcript vector, pWClMV-4 (Beck et al. 1990), was restricted with $P v u \mathrm{I}$ and the first 450 nucleotides of the WCIMV genome were labeled with $\left[\alpha-{ }^{32} \mathrm{P}\right]-\mathrm{UTP}$ in a transcription reaction (Beck et al. 1990). The resulting RNA transcript was purified over a Microspin S-300 spin column (Pharmacia Biotech). Typically, $5 \mathrm{ng}$ of transcript and 0.3 to 5 $\mu \mathrm{g}$ of $\mathrm{CP}$, or TGB1, were used in a $10-\mu l$ binding reaction. Appropriate constituents were incubated for $10 \mathrm{~min}$ at room temperature in buffer (10 mM Tris-HCl, $\mathrm{pH} 8.0,1 \mathrm{mM}$ EDTA, $5 \mathrm{mM} \mathrm{MgSO}_{4}, 1 \mathrm{mM}$ dithiothreitol [DTT], 10\% [vol/vol] glycerol, and $200 \mathrm{mM} \mathrm{NaCl}$ ). The reaction products were electrophoresced at $100 \mathrm{~V}$ in a continuous, nondenaturing (native) $5 \%$ polyacrylamide gel in $1 \times$ Tris-buffered EDTA (Ready Gel, BioRad, Hercules, CA) at $4^{\circ} \mathrm{C}$ for $4 \mathrm{~h}$. All steps were carried out in the absence of ATP. Following electrophoresis, radioactivity was detected with a PhosphorImager (Storm 840, Molecular Dynamics, Sunnyvale, CA).

\section{Confocal laser scanning imaging.}

Movement of fluorescent probes within the mesophyll of wild-type and transgenic $N$. benthamiana leaves was observed through a Leitz Orthoplan epi-illumination microscope equipped with a Hamamatsu VIM C1966-20 analytical system (Wolf et al. 1989) or a Leica model TCS-4D (Leica, Heidelberg, Germany) upright CLSM. All permanent images were obtained with the Leica CLSM, using long-working distance multimedia objectives $(\times 16, \times 25$, and $\times 40)$. A low intensity laser ( $25 \mathrm{~mW}$ krypton/argon laser) was used to image the spatial distribution of FITC-, CY3.5-, TOTO-, and CF-UTPlabeled probes and Hoechst DNA-specific stain 33342. Simultaneous three-channel recordings were made with the following filter sets: (i) FITC, $488 \mathrm{~nm}$ excitation, $525 \mathrm{~nm}$ emission; TOTO, $514 \mathrm{~nm}$ excitation, $533 \mathrm{~nm}$ emission; chlorophyll autofluorescence, excitation $488 \mathrm{~nm}$, emission, >620 nm; (ii) CF-UTP, $488 \mathrm{~nm}$ excitation, $525 \mathrm{~nm}$ emission; CY3.5, $580 \mathrm{~nm}$ excitation, $596 \mathrm{~nm}$ emission with a $620 \mathrm{~nm}$ cut off filter; chlorophyll autofluorescence, excitation $488 \mathrm{~nm}$, emission $>620$ $\mathrm{nm}$; (iii) Hoechst 33342, excitation $350 \mathrm{~nm}$, emission $440 \mathrm{~nm}$. All experiments were conducted and analyzed with the same laser power and photomultiplier settings. At the conclusion of an experiment, data files were transferred to a Power Mac 8500 workstation. Image analysis, display (adjustments in contrast, brightness, etc.) and preparation for plates were all performed with Adobe Photoshop (Adobe Systems, Mountain View, CA).

\section{ACKNOWLEDGMENTS}

We thank Mark Andersen, Davin Voot, Craig van Dolleweerd, and Michele Androvich for technical assistance, Paul Sutherland for electron microscopy, Catherine Bryant for assistance with some gel mobility-shift assays, Sabine Bouché-Pillon for assistance with some injection experiments, and K. C. McFarland for his expertise in the presentation of confocal images and figures. This work was supported by grants from the National Science Foundation, grant IBN-9406974 (W. J. L.) and the New Zealand Foundation for Research Science and Technology (R. L. S. F.)

\section{LITERATURE CITED}

Angell, S. M., and Baulcombe, D. C. 1995. Cell-to-cell movement of potato virus $X$ revealed by micro-injection of a viral vector tagged with the $\beta$-glucuronidase gene. Plant J. 7:135-140.

Angell, S. M., Davies, C., and Baulcombe, D. C. 1996. Cell-to-cell movement of potato virus $\mathrm{X}$ is associated with a change in the sizeexclusion limit of plasmodesmata in trichome cells of Nicotiana clevelandii. Virology 216:197-201.

Atkins, D., Hull, R., Wells, B., Roberts, K., Moore, P., and Beachy, R. N. 1991. The tobacco mosaic virus $30 \mathrm{~K}$ movement protein. J. Gen. Virol. 72:209-211.

Baulcombe, D. C., Chapman, S., and Santa Cruz, S. 1995. Jellyfish green fluorescent protein as a reporter for virus infections. Plant J. 7: 1045-1053.

Beck, D. L., Forster, R. L. S., Bevan, M. W., Boxen, K. A., and Lowe, S. C. 1990. Infectious transcripts and nucleotide sequence of cloned cDNA of the potexvirus white clover mosaic virus. Virology 177:152158.

Beck, D. L., Guilford, P. J., Voot, D. M., Andersen, M. T., and Forster, R. L. S. 1991. Triple gene block proteins of white clover mosaic potexvirus are required for transport. Virology 183:695-702.

Beck, D. L., Van Dolleweerd, C. J., Lough, T. J., Balmori, E., Voot, D. M., Andersen, M. T., O'Brien, I. E. W., and Forster, R. L. S. 1994. Disruption of virus movement confers broad-spectrum resistance against systemic infection by plant viruses with a triple gene block. Proc. Natl. Acad. Sci. USA 91:10310-10314. 
Chang, B.-Y., Lin, N.-S., Liou, D.-Y., Chen, J.-P., Liou, G.-G., and Hsu, Y.-H. 1997. Subcellular localization of the $28 \mathrm{kDa}$ protein of the triple-gene-block of bamboo mosaic potexvirus. J. Gen. Virol. 78:11751179.

Chapman, S., Hills, G., Watts, J., and Baulcombe, D. 1992. Mutational analysis of the coat protein gene of potato virus $\mathrm{X}$ effects on virion morphology and viral pathogenicity. Virology 191:223-230.

Davies, C., Hills, G., and Baulcombe, D. C. 1993. Sub-cellular localization of the $25-\mathrm{kDa}$ protein encoded in the triple gene block of potato virus X. Virology 197:166-175.

Deom, C. M., Lapidot, M., and Beachy, R. 1992. Plant virus movement proteins. Cell 69:221-224.

Ding, B., Haudenshield, J. S., Hull, R. J., Wolf, S., Beachy, R. N., and Lucas, W. J. 1992a. Secondary plasmodesmata are specific sites of localization of the tobacco mosaic virus movement protein in transgenic tobacco plants. Plant Cell 4:915-928.

Ding, B., Li, Q., Nguyen, L., Palukaitis, P., and Lucas, W. J. 1995. Cucumber mosaic virus 3 a protein potentiates cell-to-cell trafficking of CMV RNA in tobacco plants. Virology 207:345-353.

Ding, B., Turgeon, R., and Parthasarathy, M. V. 1992b. Substructure of freeze-substituted plasmodesmata. Protoplasma 169:28-41.

Donald, R. G. K., Zhou, H, and Jackson, A. O. 1993. Serological analysis of barley strip mosaic virus-encoded proteins in infected barley. Virology 195:659-668.

Epel, B. L., Padgett, H. S., Heinlein, M., and Beachy, R. N. 1996. Plant virus movement protein dynamics probed with a GFP-protein fusion. Gene 173:75-79.

Fernandez, A., Lain, S., and Garcia, J. A. 1995. RNA helicase activity of the plum pox potyvirus CI protein expressed in Escherichia coli. Mapping of an RNA binding domain. Nucleic Acids Res. 23:13271332 .

Fiers, W., Contreras, R., Duerinck, F., Haegeman, D., Iserentant, D., Merregaert, J., Min Jou, W., Molemans, F., Raeymaekers, A., Van den Berghe, A., Volckaert, G., and Ysebaert, M. 1976. Complete nucleotide sequence of bacteriophage MS2 RNA: Primary and secondary structure of the replicase gene. Nature 260:500-507.

Forster, R. L. S., Beck, D. L., Guilford, P. J., Voot, D. M., and Andersen, M. T. 1992. The coat protein of white clover mosaic potexvirus has a role in facilitating cell-to-cell transport in plants. Virology 191:480484.

Foster, G. D., Meehan, B. M., and Mills, P. R. 1990. Nucleotide sequence of the $7 \mathrm{~K}$ gene of carnation latent virus. Plant Mol. Biol. 15: 937-939.

Fujiwara, T., Giesman-Cookmeyer, D., Ding, B., Lommel, S. A., and Lucas, W. J. 1993. Cell-to-cell trafficking of macromolecules through plasmodesmata potentiated by the red clover necrotic mosaic virus movement protein. Plant Cell 5:1783-1794.

Ghoshroy, S., Lartey, R., Sheng, J., and Citovsky, V. 1997. Transport of proteins and nucleic acids through plasmodesmata. Annu. Rev. Plant Physiol. Plant Mol. Biol. 48:27-50.

Gilbertson, R. L., and Lucas, W. J. 1996. How do viruses traffic on the "vascular highway"? Trends Plant Sci. 1:260-268.

Gleave, A. P. 1992. A versatile binary vector system with T-DNA organisational structure conducive to efficient integration of cloned DNA into the plant genome. Plant Mol. Biol. 20:1203-1207.

Habili, N., and Symons, R. H. 1989. Evolutionary relationship between luteoviruses and other RNA plant viruses based on sequence motifs in their putative RNA polymerases and nucleic acid helicases. Nucleic Acids Res. 17:9543-9555.

Hefferon, K. L., Doyle, S., and AbouHaidar, M. G. 1997. Immunological detection of the $8 \mathrm{~K}$ protein of potato virus $\mathrm{X}$ (PVX) in cell walls of PVX-infected tobacco and transgenic potato. Arch. Virol. 142:425433.

Heinlein, M., Epel, B. L., Padgett, H. S., and Beachy, R. N. 1995. Interaction of tobamovirus movement proteins with the plant cytoskeleton. Science 270:1983-1985.

Horsch, R. B., Fry, J. E., Hoffman, N. L., Eichholz, D., Rogers, S. G., and Fraley, R. T. 1985. A simple and general method for transferring genes into plants. Science 227:1229-1231.

Hull, R. 1989. The movement of viruses in plants. Annu. Rev. Phytopathol. 27:213-240.

Jefferson, R. A. 1987. Assaying chimeric genes in plants: The GUS gene fusion system. Plant Mol. Biol. Rep. 5:387-405.

Kühn, C., Franceschi, V. R., Schulz, A., Lemoine, R., and Frommer, W.
B. 1997. Macromolecular trafficking and turnover of sucrose transporters in enucleate sieve elements. Science 275:1298-1300.

Linstead, P. J., Hills, G. J., Plaskitt, K. A., Wilson, I. G., Harker, C. L. and Maule, A. J. 1988. The subcellular localisation of the gene 1 product of cauliflower mosaic virus is consistent with a function associated with virus spread. J. Gen. Virol. 69:1809-1818.

Lucas, W. J., Bouché-Pillon, S., Jackson, D. P., Nguyen, L., Baker, L., Ding, B., and Hake, S. 1995. Selective trafficking of KNOTTED1 homeodomain protein and its mRNA through plasmodesmata. Science 270:1980-1983.

Lucas, W. J., Ding, B., and van der Schoot, C. 1993. Plasmodesmata and the supracellular nature of plants. New Phytol. 125:435-476.

Lucas, W. J., and Gilbertson, R. L. 1994. Plasmodesmata in relation to viral movement within leaf tissue. Annu. Rev. Phytopathol. 32:387411.

Lucas, W. J., and Wolf, S. 1993. Plasmodesmata: The intercellular organelles of green plants. Trends Cell Biol. 3:308-315.

McLean, B. G., Hempel, F. D., and Zambryski, P. C. 1997. Plant intercellular communication via plasmodesmata. Plant Cell 9:1043-1054.

McLean, B. G., Zupan, J., and Zambryski, P. C. 1995. Tobacco mosaic virus movement protein associates with the cytoskeleton in tobacco cells. Plant Cell 7:2101-2114.

Maule, A. J. 1991. Virus movement in infected plants. Crit. Rev. Plant Sci. 9:457-473.

Morozov, S. Y., Fedorkin, O. N., Jüttner, G., Schiemann, J., Baulcombe, D. C., and Atabekov, J. G. 1997. Complementation of a potato virus X mutant mediated by bombardment of plant tissues with cloned viral movement protein genes. J. Gen. Virol. 78:2077-2083.

Morozov, S. Y., Miroshnichenko, N. A., Zelenina, D. A., Fedorkin, O. N., Solovijev, A. G., Lukasheva, L. I., and Atabekov, J. C. 1990. Expression of RNA transcripts of potato virus X full-length and subgenomic cDNAs. Biochimie 72:677-684.

Nguyen, L., Lucas, W. J., Ding, B., and Zaitlin, M. 1996. Viral RNA trafficking is inhibited in replicase-mediated resistant transgenic tobacco plants. Proc. Natl. Acad. Sci. USA 93:12643-12647.

Niesbach-Klosgen, U., Guilley, H., Jonard, G., and Richards, K. 1990. Immunodetection in vivo of beet necrotic yellow vein virus-encoded proteins. Virology 178:52-61.

Noueiry, A. O., Lucas, W. J., and Gilbertson, R. L. 1994. Two proteins of a plant DNA virus coordinate nuclear and plasmodesmal transport. Cell 76:925-932.

Oparka, K. J., Roberts, A. G., Roberts, I. M., Prior, D. A. M., and Santa Cruz, S. 1996. Viral coat protein is targeted to, but does not gate, plasmodesmata during cell-to-cell movement of potato virus X. Plant J. 10:805-813.

Padgett, H. S., Epel, B., Kahn, T. W., Heinlein, M., Watanabe, Y., and Beachy, R. N. 1996. Distribution of tobamovirus movement protein in infected cells and implications for cell-to-cell spread of infection. Plant J. 10:1079-1088.

Rojas, M. R., Zerbini, F. M., Allison, R. F., Gilbertson, R. L., and Lucas, W. J. 1997. Capsid protein and helper component-proteinase function as potyvirus cell-to-cell movement proteins. Virology 237:283-295.

Rouleau, M., Smith, R. J., Bancroft, J. B., and Mackie, G. A. 1994. Purification, properties, and subcellular localization of foxtail mosaic potexvirus 26-kDa protein. Virology 204:254-265.

Rouleau, M., Smith, R. J., Bancroft, J. B., and Mackie, G. A. 1995. Subcellular immunolocalization of the coat protein of two potexviruses in infected Chenopodium quinoa. Virology 214:314-318.

Sambrook, J., Fritsch, E. F., and Maniatis, T. A. 1989. Molecular Cloning: A Laboratory Manual. 2nd ed. Cold Spring Harbor Laboratory, Cold Spring Harbor, NY.

Sit, T. L., Leclerc, D., and AbouHaidar, M. G. 1994. The minimal 5' sequence for in vitro initiation of papaya mosaic potexvirus assembly. Virology 199:238-242.

Studier, F. W., Rosenberg, A. H., Dunn, J. J., and Dubendorff, J. W. 1990. Use of T7 RNA polymerase to direct expression of cloned genes. Methods Enzymol. 185:60-89.

Tomenius, K., Clapham, D., and Meshi, T. 1987. Localization by immunogold cytochemistry of the virus-encoded $30 \mathrm{~K}$ protein in plasmodesmata of leaves infected with tobacco mosaic virus. Virology 160:363-371.

Wolf, S., Deom, C. M., Beachy, R. N., and Lucas, W. J. 1989. Movement protein of tobacco mosaic virus modifies plasmodesmatal size exclusion limit. Science 246:377-379. 